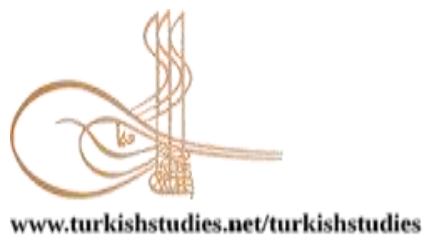

Turkish Studies

eISSN: $1308-2140$

Research Article / Araștırma Makalesi

\title{
II. Mahmut'un Temel Eğitimin Zorunluluğuna İlişkin 1824 Tarihli Talim-i Sıbyan Fermanının Çocuk Hakları Açısından İncelenmesi*
}

\author{
Examination of Mahmut II's 1824 Edict of Talim-i Sibyan (Education of Infants) on the Compulsion \\ of the Primary Education in Terms of the Rights of the Child
}

\author{
Ali Gurbetoğlu**
}

\begin{abstract}
The rights of the child and the exploitation of child labor are among the most fundamental child problems in history. The rights of the child have come into question in the Western world in the early 20th century as a legal text aimed directly at protecting children. The most comprehensive legal document on this subject is the "United Nations Convention on the Rights of the Child" of 1989. In ancient Turkish culture, there were some practices regarding the protection and upbringing of the child determined based on the customs. The "Edict of Talim-i Slbyan (Education of Infants)" of 1824 in the Ottoman Empire is one of the first legal written documents aimed at solving the problems in this area. This edict was mainly deemed as the first legal text making primary education compulsory. As one of the first documents making primary education compulsory in Turkey, the edict has been referred to frequently in scientific studies. In the contents of the edict, the emphasis was placed on the prevention of exploitation of child labor and the preparation of children for life through education. This edict, which is known as the first written legal document in the field of the rights of the child in Turkey, gains importance with this content. In this context, the edict has been one of the most significant documents in the field of the rights of the child both in the world and in Turkey. The main objective of this study was to examine and introduce the "Edict of Talim-i Slbyan (Education of Infants)" dated 1824 of Mahmut II. Another objective is to evaluate the relevant edict in terms of the rights of the child. The research was conducted in a document review pattern based on the qualitative method. The "Edict of Talim-i Sibyan (Education of Infants)" was used as the main source in the study. The edict in question was extracted from the Ottoman original of Ahmet Cevdet Pasha's work named "Tarih-i Cevdet (History of Cevdet)". The contents of the edict were given in Ottoman original as well as translated into modern Turkish. It is clear that the edict was intended to secure the rights of "development" and "protection" that are among the four basic areas secured in the 1989 United Nations Convention on the Rights of the Child. The two issues that come to the fore in the edict are the "necessity of primary education" and the "prevention of exploitation of child labor". The first one relates to the child's "right to development" and the second one relates to the "right to protection". The edict emphasized the importance of learning basic religious knowledge and also pointed to the spread of ignorance due to the indifference of parents. It is stated that the main reason for this is that the families send children to work instead of school to make money. For this reason, attention has been drawn to the spread of ignorance in society and the importance of educating children as they are young. The main purpose of the edict is to dissuade the families and tradesmen from the financial income provided by child labor. To prevent the abuse of children
\end{abstract}

\footnotetext{
${ }^{*}$ Bu makale aynı adla sunulan ve özet olarak yayımlanan bildiriden üretilmiştir.

** Dr. Öğr. Üyesi, İstanbul Sabahattin Zaim Üniversitesi Eğitim Fakültesi, Eğitim Bilimleri Bölümü.

Asst. Prof., Istanbul Sabahattin Zaim University, Faculty of Education, Department of Educational Sciences. ORCID 0000-0003-3710-3516

ali.gurbetoglu@izu.edu.tr

Cite as/ Atıf: Gurbetoğlu, A. (2020). II. Mahmut'un temel eğitimin zorunluluğuna ilișkin 1824 tarihli Talim-i Sıbyan Fermanının çocuk hakları açısından incelenmesi. Turkish Studies, 15(5), 2333-2356. https://dx.doi.org/10.7827/TurkishStudies.43726

Received/Geliş: 21 May/Mayıs 2020

Accepted/Kabul: 25 August/Ağustos 2020

Copyright $\odot$ MDE, Turkey

Checked by plagiarism software

Published/Yayın: 31 August/Ağustos 2020

CC BY-NC 4.0
} 
in that way, the edict prescribed penal sanctions. In this study, the "Edict of Talim-i Sibyan (Education of Infants)", which is well known and frequently referred to by educationists, was evaluated in terms of the contemporary rights of the child. With this edict, Mahmut II did not leave children at the mercy of the parents and tradesmen and made their primary education compulsory. Thanks to the edict, it was made compulsory for children to be sent to a primary education school, instead of apprenticeships, until adolescence period. Thus, the edict helped the child to exercise his/her right to education, on the one hand, prevented abuse of child labor and prepared a healthier environment for the child's physical and mental development, on the other hand. With this nature, the edict is an important document in terms of the history of Turkish education as well as the history of Turkish childhood. It can also be said that this edict is one of the first and most important documents in the world's childhood history. This edict brought the rights of children in the areas of "development" and "protection" into question nearly a century and a half before the 1989 United Nations Convention on the Rights of the Child. In this context, the edict is a very important document in terms of Turkish and world's childhood history.

Structured Abstract: Introduction: The concept of the "rights of the child" has been known and used since ancient times. It is accepted that this concept was raised in the Western world in the early 20th century to protect children. It is known that there are some regulations on the rights of the child in Turkish culture. Some practices determined by custom for the protection and upbringing of the child are intended for this purpose. On the other hand, most children at the age of compulsory education are often forced to engage in active working life due to the need for subsistence or the economic poverties of their families. Since they are not competent, they work mostly in the status of unskilled workers, with low wages, in a manner deprived of social security and abandoned at the mercy of their employers. This is the problem of the past and the present and the future. Mahmut II's 1824 "Edict of Talim-i Sibyan (Education of Infants)" is one of the first legal documents written in Turkey in order to find a solution to the neglect of children. This document is mostly regarded as a legal document mandating primary education in the Ottoman Empire. As one of the first legal documents making education compulsory in Turkey, the references to this edict have often been made in scientific studies. Furthermore, the edict is the first known written legal document in the field of the rights of the child in Turkey. In this context, the edict is one of the most important documents in the field of the rights of the child in Turkey and the world.

\section{Objective}

This edict, which is the subject of the study, has not yet been analyzed in detail by researchers. The edict has not been evaluated in terms of the rights of the child and the history of Turkish childhood either. Therefore, the main purpose of this study is to conduct a detailed analysis of the edict. Another goal is to review and evaluate this edict from the perspective of the rights of the child. Together with its original text and evaluation, this study will hopefully fill an important gap by bringing one of the most important written documents in Turkish childhood history into the agenda.

\section{Method}

The research was conducted in a document review pattern based on the qualitative method. In the study, the Edict of Talim-i Sibyan (Education of Infants) was used as the main source. The edict was extracted from the original Ottoman book named "Tarih-i Cevdet (History of Cevdet)" by Ahmet Cevdet Pasha. In the study, the historical development of childhood, the rights of the child, and the law on children are discussed in brief. In this sense, the basic principles of the "Convention on the Rights of the Child" are emphasized. In terms of determining the current situation, the primary education of the Ottoman Empire is summarized briefly. Then, the full text of the edict was translated from Ottoman Turkish and added to the report. The characteristics of the paper were examined in detail in terms of the rationale of the publication and the issues that it focuses on, and evaluated in terms of "the compulsion of primary education" and "the rights of the child".

\section{Findings}

In the United Nations Convention on the Rights of the Child, the most advanced and binding document on the rights of the child in the world, the rights of the child are secured in four basic areas: "survival", "development", "participation" and "protection". It is observed that the "Edict of Talim-i Slbyan (Education of Infants)", subject of the examination, is intended to secure the rights of "development" and "protection" among the four main areas secured in the convention in question. There had been no compulsory education practice for children in the Ottoman Empire until the period when the edict was issued. There was no regulation to 
prevent children from engaging in work and professional life as early as possible either. This issue was carried out entirely based on the choice of parents and the acceptance of tradesmen and artisans. With the "Edict of Talim-i Sibyan (Education of Infants)", the issue of primary education of children was freed from being left to the mercy of parents and artisans, and the state started to take care of the protection and education of children for the first time. In the edict, two issues, "the compulsion of primary education" and the "prevention of abuse of the child labor", come to the forefront. The first one of these rights relates to the "right to development" of the child and the second one relates to the "right to protection" of the child. At the core of the edict, two main objectives are evident. The first one is to dissuade families from eagerness for the financial income of child labor, the other is to discourage tradesmen who employ children for cheap labor. To prevent child abuse in this way, criminal sanctions were prescribed in the edict. In this regard, the edict brought an understanding and practice far ahead of its time in terms of taking educational measures for the child's upbringing and development in respect of physical, mental, emotional, social and moral aspects. In a sense, the edict reflects the conditions of the infant (sıbyan) schools, which are the basic educational institutions of the classical Ottoman Empire. With this edict, Sultan Mahmut emphasized the importance of primary education of children and did not leave them at the mercy of parents and tradesmen. It was made compulsory for children to be sent to school for primary education, instead of apprenticeships, until the adolescence period. Thus, the edict helped the child to exercise his/her right to education while preventing abuse of child labor and preparing a healthier environment for the physical and mental development of the child. With this feature, the edict is an important document in the history of Turkish education as well as in the history of Turkish childhood. It can even be said that this edict is one of the first and most important documents in world childhood history. In the edict, the issues such as the need to teach children basic religious knowledge, the child's ignorance due to the indifference of the parents, sending children to work instead of school, the abuse of the child labor due to the passion for money, the prevalence of ignorance in society, and the fact that educating children is compulsory when they are young, their education will become difficult as they grow are presented as the reason for the publication of the edict. In the edict, the importance of education is stated and it is emphasized that education provides happiness in the world and afterlife. Therefore, while learning business and art, the teaching of basic information called "basic religious knowledge" is not omitted. As a solution, it was decided that children are not sent to apprenticeships until the adolescent period. The tradesman shall not accept children into apprenticeships without the permission of the tradesmen manager, as well as an official document indicating the adolescent status of the children. It is also mandatory to inform the official authorities of those who do not comply with the provisions of the edict. What the officials should do in case of being informed and the exceptions for orphans are explained.

\section{Conclusion}

The determination of the rights of children and the protection of children remains one of the most important social issues from the past to the present. The fact that children are helpless and in need of protection requires adults to play an active role in their development and upbringing. In this respect, raising children has had an important place in the lives of almost every society throughout history. States have not left this issue at the mercy of individuals and each country has developed some measures and solutions. Global world conditions have necessitated that these efforts be continued with international effort. As a result of this necessity, many international official texts on the subject have been created. The most recent international document on the protection of the rights of the child is the "United Nations Convention on the Rights of the Child", adopted in 1989. This convention is the most comprehensive and binding document in this area. In the convention on the rights of the child, the rights are gathered in four basic areas: "survival", "development", "participation" and "protection". About a century and a half before this convention, the "Edict of Talim-i Sibyan (Education of Infants)" brought the development and protection of the child to the agenda and the sanctions were introduced to protect them. In this context, the convention is a very important document in terms of Turkish and world childhood history. However, many evaluations have been made about the said edict. In all these evaluations, the edict was brought up as the first legal document making the education compulsory in the history of Turkish education. Although the right to education of the child was indirectly stated in these studies, no evaluation has been made in the dimension of preventing neglect and abuse. The "Edict of Talim-i Sibyan (Education of Infants)", which is well-known and widely evaluated, was made the subject of a new evaluation and was assessed in terms of the contemporary rights of the child with this study. For this reason, in order to understand the importance of this document for the rights of the child, a new perspective has been introduced for the edict. 
Keywords: History of education, childhood history, child labor, the rights of the child, compulsory education.

Öz: Çocuk hakları ve çocuk işgücünün istismarı tarihin en köklü çocuk sorunlarındandır. Çocuk hakları, doğrudan çocukları korumaya dönük yasal bir metin halinde 20. yy. başlarında Batı dünyasında gündeme gelmiştir. Bu konuda en kapsamlı yasal belge 1989 tarihli "Birleşmiş Milletler Çocuk Hakları Sözleşmesi”dir. Eski Türk kültüründe çocuğun korunması ve yetiştirilmesine ilişkin törelerle belirlenmiş birtakım uygulamalar mevcuttur. Osmanlı'da 1824 tarihli “Talim-i Sıbyan Fermanı”, bu alanda yaşanan problemlerin çözümüne yönelik ilk yasal yazılı belgelerden biridir. Bu ferman daha çok temel eğitimi zorunlu hale getiren ilk yasal metin olarak görülmüştür. Türkiye'de eğitimi zorunlu kılan ilk belgelerden biri olarak fermana bilimsel çalışmalarda sıklıkla atıfta bulunulmuştur. İçeriğinde, çocuk işgücünün istismar edilmesinin önlenmesi ve çocukların eğitim yoluyla hayata hazırlanması konusuna vurgu yapılmıştır. Türkiye'de çocuk hakları alanında ilk yazılı yasal belge olarak bilinen bu düzenleme içeriği itibariyle önem kazanmaktadır. Bu bağlamda ferman, çocuk hakları alanında hem dünyada hem de Türkiye'de en önemli belgelerden biri olmuştur. Bu çalışmanın temel amacı II. Mahmut'un 1824 tarihli "Talim-i Sıbyan Fermanını" incelemek ve tanıtmak, bir diğer amacı ise ilgili ferman'1 çocuk hakları açısından değerlendirmektir. Araştırma, nitel yönteme dayalı doküman incelemesi deseninde yapılmıştır. Çalışmada “Talim-i Sıbyan Fermanı” temel kaynak olarak kullanılmıştır. Söz konusu ferman Ahmet Cevdet Paşa'nın “Tarih-i Cevdet” adlı eserinin Osmanlıca aslından elde edilmiştir. Fermanın içeriği Osmanlıca aslıyla verilmiş ayrıca günümüz Türkçesine de aktarılmıştır. Ferman'ın 1989 tarihli Birleşmiş Milletler Çocuk Hakları Sözleşmesi'nde güvence altına alınan dört temel alandan "gelişme" ve "korunma" haklarını güvence altına almaya yönelik olduğu açıkça görülür. Fermanda öne çıkan iki husus; "temel eğitimin zorunluluğu" ve "çocuk işgücünün istismarının önlenmesi”dir. Bunlardan ilki, çocuğun "gelişim hakkı", ikincisi, "korunma hakkı" ile ilgilidir. Ferman'da; temel dini bilgileri öğrenmenin önemi vurgulanmış, aynı zamanda ebeveynlerin duyarsılı̆ğ nedeniyle cehaletin yayılmasına işaret edilmiştir. Bunun temel sebebinin ailelerin çocukları para kazanmak amacıyla okul yerine çalışmaya göndermeleri olduğu belirtilmiştir. Bu nedenle, cehaletin toplumda yaygınlaşmasına ve çocukları gençken eğitmenin önemine dikkat çekilmiştir. Fermanda asıl amaç, ailelerin ve esnafın çocuk işgücünün sağlayacağı mali gelire karşı cesaretini kırmaktır. Çocukların istismarını önlemek amacıyla cezai müeyyideler öngörülmüştür. Bu çalışmada, eğitimciler tarafından iyi bilinen ve sıklıkla dile getirilen "Talim-i Sıbyan Fermanı” çağdaş çocuk hakları açısından değerlendirilmiştir. II. Mahmut, bu fermandaki hükümlerle çocukları ebeveynlerin ve esnafin insafına terk etmemiş ve temel eğitimlerini zorunlu hale getirmiştir. Ferman ile çıraklık yerine, ergenlik çağına kadar çocukların temel eğitim okuluna gönderilmesi zorunlu hale getirildi. Böylece, ferman çocuğa eğitim hakkını kullanmada yardımcı olmuş, diğer yandan çocuk işgücünün kötüye kullanılmasını engellemiş ve çocuğun fiziksel ve zihinsel gelişimi için daha sağlıklı bir ortam hazırlamıştır. Bu özelliğiyle Türk çocukluk tarihinin yanı sıra Türk eğitim tarihi açısından da önemli bir belgedir. Ayrıca bu fermanın, dünya çocukluk tarihinin ilk ve en önemli yasal belgelerinden biri olduğu söylenebilir. Bu ferman, 1989 tarihli Birleşmiş Milletler Çocuk Hakları Sözleşmesi'nden yaklaşık bir buçuk yüzyıl önce çocukların "gelişme" ve "korunma" alanındaki haklarını gündeme getirmiştir. Bu bağlamda, ferman Türk ve dünya çocukluk tarihi açısından son derece önemli bir belgedir.

Anahtar Kelimeler: Eğitim tarihi, çocukluk tarihi, çocuk işgücü, çocuk hakları, zorunlu eğitim

\section{Giriş}

Çocuklar toplumun geleceğidir. Onların ruhsal, zihinsel ve bedensel sağllklı bir gelişme göstermesi, toplumun geleceğinde üstlenecekleri rolleri açısından önemlidir. Çocuklar bu rollerine eğitimle hazırlanırlar. Bu eğitim çalışması çok yönlü faaliyetler içerir ki, bunların başında oyun, öğrenme ve eğitim faaliyetleri gelir. Bu süreçte yetişkinlerin koruması ve desteğine muhtaç olurlar. Çocuk bir canlı, bir insan olarak korunup beslenmeye, yetiştirilmeye layık olduğu gibi toplumun geleceğinde üstleneceği rolleri açısından da böyle bir ihtimama layıktır.

Çocukları konusunda duyarlı olmayan toplumların güvenli bir gelecek beklentileri muhaldir. Dolayısıyla bir toplumun çocuklarına gösterdiği duyarlık düzeyi o toplumun kültürü hakkında da bir fikir verir. Gelişmiş toplumlar çocuğu bir insan olarak ve toplumun geleceğini yüklenecek bir değer olarak görüp önemseyen toplumlardır. Onun için bilinen en eski toplumlardan beri çocukların 
beslenmesi, büyütülmesi, eğitilmesi en önemli konulardan birisi olarak görülmüştür. Bu konuda görev sadece temel toplumsal kurum olan aile ile sınırlı kalmamış, süreç içerisinde onun çok yönlü gelişimi için her dönemde mevcut şartlara göre yeni kurumsal yapılar oluşmuştur. Zamanla çocuklara dönük hukuk kuralları ortaya çıkmış, çocukların beslenip büyütülmesi ve eğitimi sadece ailelerin inisiyatifine bırakılmamış, süreç içinde devletler bu amaçla çeşitli kurumlar oluşturmuşlardır.

Çocuğun yetişmesi, bedensel, zihinsel, duygusal, sosyal ve ahlaki gelişimi ile eğitsel önlemlerin alınmasının yanısıra onun aile ve toplum içindeki yerini düzenleyen hukuk kurallarına bağlıdır (Akyüz, 2012: 1). Çocuk bir insan olarak doğuştan birtakım haklara sahiptir. Bunların başında beslenme, büyüme ve eğitim hakkı gelir. Çocuk hem bedenen hem ruhen hem de zihni ve bedeni yetkinlikler açısından desteğe muhtaçtır. Onu bu konularda desteklemek yetişkinlerin görevidir. İhtiyaçları karşılanmayan, doğuştan sahip olduğu haklarından mahrum bırakılan çocuklar, aktif üyesi olacakları toplumda yüklenecekleri görevlere gereğince hazır olamazlar. Bununla birlikte çocuk algısı ve çocukluk anlayışının oluşmasında toplumsal şartların gelişmesi kadar, zihinsel kültürel evrimin de önemli katkısı olmuştur (Doğan, 2000: 176). Zaman ilerledikçe ebeveynlerin yetişmesinde temel olan bilgi ve tecrübe birikimi çoğalmış, her bir sonraki kuşağın çocuklara dönük bilgi ve anlayışları, öncekilere göre daha olumlu yönde değişmiştir. Kant'in da vurguladığı gibi (2007: 37) çocukları, içinde bulundukları zaman diliminden çok gelecek için eğiterek hayata hazırlamaya çalışmışlardır.

On dokuzuncu yüzyıldan günümüze çocukluk kavramı etrafında yapılan çeşitli tartışmalar, çocuğun eğitim ihtiyacına yapılan vurgular, çocuk merkezli eğitim anlayışı konusundaki gelişmeler sayesinde çocukluk kavramı daha belirgin hale gelmiştir. Böylece çocukluğun, yetişkinlikten önceki zorunlu bir evre olduğu ve yetişkinlikten oldukça farklılıklar gösterdiği düşüncesi genel kabul görmüştür. Onun eğitiminin devlet kontrolünde zorunlu olarak sağlanması genel kabuller arasına girmeye başlamışırır.

Türkiye'de eğitimin zorunlu hale getirilmesinin ilk yasal belgesi II. Mahmut'un 1824 tarihli fermanıdır. Bu ferman bir yandan çocuğun eğitim hakkına vurgu yaparken diğer yandan çocuğun korunması ve işgücünün istismarının önlenmesine dönük hükümler içermesi bakımından ayrı bir öneme sahiptir. Ferman aynı zamanda Türk eğitim sisteminin modernleşmesine yönelik atılan adımların ilk resmî belgelerinden biridir. Daha sonra bu konuda başta anayasal düzenlemeler olmak üzere yapılan çeşitli düzenlemelerle bu hükümleri işler hale getirilmeye çalışılmıştır. Ferman, günümüz uluslararası metinlerde yer alan çocuk hakları konusundaki belirlemelerle büyük ölçüde uyum içindedir. Fermanın ayrıntılı incelenmesinden anlaşılacağı üzere yayımlandığı dönemde çağının çok ilerisinde hükümler içerdiği görülür. Bu bakımdan ferman, günümüz çocuk haklarına ilişkin yasal metinlerle karşılaştırılabilecek belirlemeler içermektedir.

Ferman eğitimciler tarafından iyi bilinen bir metindir. Eğitim alanında yapılan çeşitli çalışmalarda Türkiye'de eğitimi zorunlu hale getiren ilk yasal belge olarak bu fermana muhtelif atıflar yapılmaktadır. Bunula birlikte fermanın çocuk hakları konusunda içerdiği hükümlerden söz edilmemektedir. Bunun başlıca sebeplerinden birisi Osmanlı alfabesiyle yazılmış olan fermanın günümüz Türkçesiyle tam metin olarak okuyucuların hizmetine sunulmamış olması olabilir. Bu çalışmada söz konusu ferman, Osmanlı alfabesiyle ve latinize edilmiş haliyle verilmiş, ayrıca günümüz Türkçesine çevrilmiş haliyle tam metin halinde verilmiştir.

\section{2. Çocukluğun Tarihsel Gelişimi ve Çocuk Hakları}

Çocukluğun kendine has dünyası uzun yüzyıllar boyu geriye doğru incelenebilir. Bunun her devirde eğitsel, sosyal, ekonomik, dini, siyasi, ideolojik boyutlarıyla ayrı ayrı değerlendirilmesi mümkündür. Dinlerin, toplumların, iktidarların üretim ve tüketim süreçlerinin çocuğa bakış1 devirlere göre değişim gösterir. Özellikle modern zamanlarda çocuğa yönelik bütün tutum ve telakkilerde çok hızlı gelişmeler yaşanmıştır. Beslenme, barınma, giyinme, kimlik, işgücü, oyun, eğlence gibi çeşitli unsurlar çocukluğun sosyal ve tarihsel gelişiminin belirgin bazı parametreleridir. 
Zamana ve topluma göre bu parametrelerde yaşanan değişiklikler, çocukluğun tarihi açısından değerlidir. Bilinen bir husus, tarihte geriye doğru gittikçe çocuk bakımının gerilemekte olduğu; öldürme, terk, dövme, işkence ve istismar örneklerinin artmakta olduğudur. Her kuşağın çocuk sevgisi ve çocuk bakımına ilişkin bilgi ve becerileri önceki kuşağa kıyasla daha ileridir. Bu bakımdan her yeni kuşağın toplumsal gelişmeye katkısı öncekinden daha fazla olmuştur (Tan, 1994: 23). Bu bakımdan çocukluk kavramının ve çocuk hakları konusunun tarihsel süreç içerisinde olumlu bir gelişim gösterdiği süreç üzerinden izlenebilir.

Çocuk hakları ve çocukluk kavramının gelişim süreci bir yönüyle tarihsel şartların gelişmesinin eseri olmakla birlikte, bilimin gelişmesi ve felsefi alanda çocuk olgusuna yönelik düşünsel gelişmeler de bu paradigmanın oluşumunda etkili olmuştur. Bu tarihsel süreçte "çocuk hakları" adına hareketlerin ortaya çıkması oldukça yeni sayılır. Osmanlı'da temel eğitimin zorunlu hale getirilmesinde ilk yasal belgelerden biri olarak bilinen fermanın, Türk çocukluk tarihi ve çocuk hakları açısından değerlendirilebilmesi için çocukluğun Batı'da ve Türkiye'de tarihsel gelişiminin kısa seyri ve çocuk hakları kavramının doğuşunun nasıl gerçekleştiğine kısaca göz atmak gerekir.

\section{1. Çocukluğun Tarihsel Gelişimi}

Antik dönem toplumlarında çocuklara yönelik ilgi ve tutumlar hakkındaki çok ayrıntılı bilgiler mevcut değildir. Bununla birlikte o dönemlerle ilgili mevcut bilgilerden, çocuklara dönük tutum ve yaklaşımlardan, çocuk ve çocukluk algıları hakkında dolaylı olarak sınırlı bilgiler edinilmektedir. Özellikle beslenme ve korunmanın büyük ölçüde güce dayanması sebebiyle güçlü ve sağlıklı insan yetiştirmek her toplumda önemli görülmüştür. Örneğin, eski Yunan'da ideal insan, vücut eksikliği olmayan, her türlü zorluğa direnç gösteren insandır (Mutluay,2007: 82). Bu yüzden çocuklar bir mal gibi, aile reisi olan babanın tercihine göre kabul veya reddedilmekteydi. $\mathrm{Bu}$ reddetmede çocuğun bedeni ve zihni sağlik durumu, cinsiyeti veya ailenin ekonomik durumu etkili olmaktaydı (Mutluay,2007: 52). Erkek çocuk muteber kabul edilmekte, erkek çocuğu olan anneler itibar görmekteydi (Mutluay,2007: 54). Çinliler ve Romalılar'da da aile reisi, eşini ve çocuklarını satmak ve öldürmek haklarına sahipti (Gökalp, 1991: 291). Çocuk ailenin malı olarak herhangi bir hakka malik değildi. Aynı durum Romalılarda da geçerlidir. Romalı baba, hiçbir hakka sahip olmayan çocuğu kabul veya reddedebilirdi (Mutluay,2007: 103). Çocuk, hareketlerinde aklını kullanamadığ 1 için erdeme ulaşamazdı. Kendi haline bırakılacak olursa mutsuzluk ve huzursuzluk kaynağı olurdu. $\mathrm{Bu}$ bakımdan baba ile çocuk arasında ilişkileri düzenleyecek bir haktan söz edilemezdi. Çocuğun mutlak olarak babasına ait olması bir haksızlık olarak görülmemekteydi (Bumin, 1983: 19). Baba çocuğunu dilediği gibi cezalandırır, alıp satabilir, sakat bırakabilir ve öldürebilirdi (Bumin, 1983: 12). Bizans'ta ise çocukluk, antik Roma etkileri gösterse de esas belirleyici olan Hıristiyanlığın Ortaçağ skolastik çocukluk anlayışıdır.

Hıristiyanlık toplumsal sınıfları kaldırmış olsa da çocuğa yönelik geleneksel eşya bakışı pek değişmemiş, üstelik çocuklar "asli suç" inancıyla suçlu ilan edilmiştir. Bu sebeple Fransız tarihçi Philip Aries (1914-1984) Ortaçağ'da çocukluk kavramından söz edilemeyeceğini söylemektedir. Aries'e göre Ortaçağ'da (beşinci ve on üçüncü yüzyıllar arası) çocukluk, hayatın farklı bir dönemi olarak görülmüyor, altı ile on sekiz yaş arası yılların, çocuğun zihinsel ve bedensel gelişimi için belirleyici olduğu dikkate alınmıyordu (Gander, Gardiner, 2004: 26). Batı'da çocukların eğitimine ilişkin tutumlarda 1500'lü yılların sonlarına doğru yaşanan gelişmelerle çocuğa karşı duyarlılık belirmeye başladı. Bu dönem modern eğitimin de başlangıç yılları olarak kabul edilir (Ergün, 2018: 2). Ancak bu dönemde de çocuğun aile içindeki konumunda pek bir değişiklik olmamıştı.1639'daki bir bildiri babalara, kendilerine kötü davranan çocuklarını yargılamadan hapsettirme yetkisini veriyordu. Cezanın süresini ve cinsini tespit eden babaydı. (Bumin, 1983: 47). Bununla birlikte süreç içinde çocukların görüp öğreneceği şeylerin yetişkinlerden farklı olmasına dikkat edilmeye başlanmış, böylece çocuğun, yetişkinden farklı bir kişilik olarak algılanması süreci gittikçe önem kazanmıştır (Onur, 1994: 3). Aynı şekilde çocukların sağlığına, eğitimine ve ahlaki gelişimine ilgide 
büyük artışlar görülmüştür. Böylece, Ortaçağ boyunca bir yetişkin gibi muamele gören çocukların durumu, on yedinci yüzyıldan itibaren gelişmeye başlayan modern devlet ve toplum algısıyla birlikte değişmeye başladı. Böylece çocukluğun hiç tanınmadığı bir çağdan, hukuksal, toplumsal, eğitsel kurumlar içinde korunmaya alınan bir çocukluk kavramına geçiş tam dört yüzyıl sürmüştür (Onur, 1994: 5). Modern çağın gelişen ve değişen anlayışında devletin vatandaşlarını geliştirme, eğitme, imkan ve şartlarını iyileştirme gibi yeni görevler üstlenmesi, çocuk ve çocukluk kavramlarının da çok önemli değişikliklere uğramasına vesile oldu. Modern devlet, geleceğin nitelikli vatandaşlarını yetiştirmenin ilk evresi olarak çocukların eğitiminde inisiyatif üstlendi. Böylece zorunlu eğitimin başlangıcı modern çocukluğun da başlangıcı olarak kabul edilmektedir (Bumin, 1983: 33-35).

Eski Türk kültüründe de çocukluk algısı ana hatlarıyla antik dönem paradigmasıyla uyumluluk gösterir. Eski Türklerde çocuğun terbiyesinden, ailenin reisi olan baba sorumluydu (Ögel, 200: 69). Çocuk, neslin ve devletin devamının garantisi olarak çok önemli görülmekteydi. Bu amaçla özelikle erkek çocuklar en sert şartlarda yetiştirilirlerdi, daha küçücük bir çocukken soğuğa, açlığa, yorgunluğa dayanmayı öğrenirlerdi (Roux, 2008: 132). Çocuğun eğitiminde, onun hayata hazırlanması esas amaç olduğundan bu hazırlık evresinin olabildiğince erken bir süreçte tamamlanması önemliydi (Gurbetoğlu, 2014: 170). Oğuz Kağan destanında Oğuzhan'ın kırk gün geçmeden yürümesi, onun bir an önce hayata atılmasının sembolik ifadesidir. Nitekim eski Türklerde çocuklar üç-dört yaşlarından itibaren, kuzuya, koyuna bindirilerek ve ok ile tarla faresi ve sincap avlatılarak, biniciliğge ve vuruculuğa alıştırılırdı. Henüz yürümeğe başlayan her çocuğun yanında eğerlenmiş bir at hazır bulunurdu (Kafesoğlu, 1998: 241). Bununla birlikte Türklerin, Romalılar'da olduğu gibi çocuklarını satmak veya öldürmek gibi bir yetkileri yoktu. Türkler arasında böyle bir vahşet hiçbir zaman görülmemiştir (Gökalp, 1991: 291). Büyük bir özenle büyütülen çocuk on beş yaşına gelince ve bir kahramanlık yaparak rüştünü ispat edince ailenin özel yetkesinden çıkardı (Gökalp, 1991: 302). Bütün bunlar çocuğun eğitilmesinin ne kadar önemli görüldüğünün göstergeleridir. Temel eğitimin verildiği mektep, muhtemelen Göktürk çağından beri mevcut idi (Baykara, 2001: 187). Bununla birlikte bu eğitimin hangi mekanlarda ve ne tür programlarla yürütüldügüne ilişkin yeterli bilgiler mevcut değildir. Eski Türklerde eğitimin bir statü kazandırma aracı olduğu da görülmektedir. Bir Uygur atasözünde "çocuğu okula ver, oradan alıp saraya ver" (Akyüz, 2019: 15) sözü çocuğun geleceği açısından eğitimin önemine işarettir.

İslam'ın kabulünden sonra Türklerde çocuk ve aile kurumu neslin devamını sağlamada aynı şekilde önemini korumuştur. Bu dönemde de çocuk sahibi olmak ve onu en iyi şekilde yetiştirip topluma kazandırmak ailenin en temel görevi kabul edilmiştir. Bu amaçla devletin oluşturduğu kurumsal yapılarda çocuklar geleceğe hazırlanmışlardır.

Çocukluğun, hayatın ayrı bir dönemi haline dönüşmesini sağlayan başlıca gelişmeler; tarımdan sanayiye kayan bir ekonomi, gelişen orta sınıf, değişen aile yapısı ve rolleri, azalan çocuk ölümleri, artan boş zamanlar, ana-baba-çocuk ilişkisinde önem kazanan duygusal bağlar gibi muhtelif nedenlere bağlanmaktadır. Bu sürece, aydınlanma çağı filozoflarının çocukluk anlayışı ve çocuk eğitimine ilişkin yeni görüşleri de katkılar sağlamıştır. Böylece kendine özgü, dinamik, gelişime açık bir çocukluk anlayışı ortaya çıkmıştır (Onur, 1994: 4).

Geleneksel imkân ve anlayışların değişmesiyle çocuk algıları da değişmiş, böylece çocukluk tarihi, gelenekselden moderne doğru bir değişme ve gelişme göstermiştir. Bu süreçte çocukluğun gittikçe daha özgür, daha özgün, daha çok haklara sahip, daha çok önemsenen, topluma katılım süreçlerini daha etkin kullanabildiği söylenebilir. Rönesans'la, Ortaçağ'ın insanı "günahkâr" olmaktan çıkmış, "yaratan" karşısında belli ilişki çerçevesinde bir "özne" durumuna gelmişti (Bumin, 1983: 17). Aydınlanma döneminde aklın ve deneyimin önem kazanması ve pozitif bilimlerde sağlanan gelişmeler sonucu keşfedilen makine, üretimi "kol gücünden makine gücüne" çevirerek yeni bir paradigma üretmişti. Bu paradigma "demir ile kömürün sihirli gücün"den doğmuştu. Bu sihirli güç modernizmin de başlangıcı olmuştur. Böylece yeni dönemde üretim 
aygıtındaki yenilikler, iş bölümü ve dolayısıyla bir hiyerarşiyi beraberinde getirdi (Bumin, 1983: 25). Eğitim sistemleri bu hiyerarşiye eleman yetiştirmek üzere yeni bir anlayışla şekillendirildi. Üretim biçiminde meydana gelen değişim, meslek öğrenmeyi de zorunlu hale getirmiş, nitelikli işgücü ihtiyacı, eğitime olan ihtiyacı da artırmıştı. Geleneksel yapıda ekonomik birim olarak hemen her şey aile içinde gelişirken çocuğun eğitimi ve hemen tüm ilişkileri aile çevresiyle sınırlıydı. Sanayi devrimi ailenin de işlevini değiştirdi. Ekonomik örgütlenme aile ortamı dışına taşınca çocuklar da aile dışında ekonomik hareketliliğe katılmak için temel ve mesleki eğitimlerini gerçekleştirmede aile dışında hareketli olmaya başladılar. Bu süreçte çocuğun refahı, sağlık sorunları, korunma ihtiyacı gibi alanlarda ailenin fonksiyonu, toplumun sorumluluğuna intikal etti. Bütün bunlar kamu eğitimi düşüncesini doğurmuştur (Doğan, 2000: 156). Zorunlu eğitim kavramı böyle bir süreçte ortaya çıkmıştır.

Eğitimci Tan, (1994) 20. yüzyıl çocuk paradigmasının 18. yüzyıl aydınlanmasının ürünü olduğunu, bir yandan J.J. Rousseau'nun "Romantik", diğer yandan J. Locke'un "Protestan" çocuk anlayışından esinlenerek iki boyutta geliştiğini söyler. Romantik anlayışta çocuğun kendi başına önemli ve yetişkinden farklı olduğuna dikkat çekilir. Her yaş kademesinde değerli psikolojik özellikler taşıdığına vurgu yapılır. Protestan anlayışta ise çocuk, geleceğin yurttaşı, iş adamı olarak düşünüldüğü için çocuğun düşünsel gelişimini bu modele uygun gerçekleştirecek bir yetiştirme biçimi önemlidir. Zihin doğuşta bir "tabula rasa" gördüğünden, üstüne yazılacak olanlardan sırasıyla anne-babalar, öğretmenler ve devlet sorumludur. Dolayısıyla, çocuğun bilgisizliği, kabalığ kendisine değil, onun yetiştirenlere aittir. Rousseau ve Locke'un görüşleri 19. yüzyıl sonunda J. Dewey ve Freud'un yayımlanan çalışmalarıyla 20.yüzyıl çocukluk anlayışının belirlenmesinde etkili olmuşlardır. J. Dewey'in felsefe, Freud'un psikoloji alanında çocukluk sorununa yöneldikleri görülmektedir. Her ikisi de çalışmalarında, Batı'da, 16. yüzyıldan 20. yüzyıla uzanan çocukluk anlayışlarının sentezini oluşturdukları ve 20. yüzyılın çocuklukla ilgili tartışmalarını biçimlendirdikleri ileri sürülmüştür. Freud, doğal gerçeklerin gözardı edilmesinin kişilik bozukluklarına neden olduğuna dikkat çekerek Locke'un "tabula rasa" fikrine karşı Rousseau'ya yakın dururken, çocuğun anne-babası ile ilk etkileşiminin yetişkin kişiliğini belirlemedeki önemine vurgu yaparak Locke'a benzer tavır sergiler. Dewey de felsefi çerçevede, çocuğun ruhsal ihtiyaçlarını, gelecek açısından değil, "şimdi" açısından ele alınması gerektiğini vurgulamıştır (Postman, 1995: 78-80). Bu düşünceler 20. yüzyıl çocukluk paradigmasının temel karakterini oluşturmuştur.

Çocukluk tarihi çalışmalarında Ortaçağ Avrupa'sında çocukluk ve aile üzerine çalışmalarıyla bilinen Philppe Aries öncü kabul edilmektedir. Çalışmalarında çağdaş aileyi inceleme konusu edinen Aries, çocukluk düşüncesiyle aile düşüncesi arasında bir bağlantı kurmuş, birinin yardımıyla diğerinin kavranabileceğini düşündügünden ikisini birlikte ele almıştı. Çalışmalarında çocukluk konusunda Ortaçağın bilgisizliğinden 19. yüzyıldaki çocuk merkezli aileye nasıl gelindiğini inceliyordu (Tan, 1994: 17). Bu amaçla "Centuries of Childhood" adlı oldukça ilgi çeken bir çalışma yapmıştı. 1960'ların başında Aries'in öncü çalışmasını izleyerek, aile tarihini konu alan araştırmaların çoğalmasıyla tarihçiler toplumsal, kültürel, ekonomik bağlamla çocukluk ve gençlik yaşantılarındaki değişmeler arasında bağlantılar kurmaya yöneldiler (Tan, 1997: 31).

\section{2. Çocuk Hakları Kavramı}

Çocuklar toplumun korunmaya muhtaç en önemli kesimidir. Onları koruyan yasalar ve ahlaki kurallar toplumlara göre farkl1lık göstermektedir. Her bir toplum, tarihsel gelişimi içinde kendi kültürü çerçevesinde çocukların hayata kazandırılması amacıyla tedbirler alagelmiştir. Toplumdan topluma değişen çocuk ve çocukluk algıs1, çocuğu koruyup geliştirme ve yetiştirmede, her toplumda farklı tutumların gelişmesinin de kaynağını oluşturmuştur. Bununla birlikte çocukluğun kurumsallaşmasının ilk evrensel belirtisi ilköğretim yaşantısı, en son göstergesi de "Çocuk Hakları" hareketidir (Onur, 1994: 5). 
Çocuk hakları, çocuğun bedensel, zihinsel, duygusal, sosyal, ahlaki ve ekonomik bakımlardan korunması ve gelişmesini sağlar (Akyüz, 2012: 3). Bu bakımdan çocuk hakları kavramını insan haklarından ayrı düşünmemek gerekir. İnsan hakları kavramı, insanların temel hak ve özgürlükleri elde etme çabalarının bir ürünü olarak doğmuştur. Günümüzde bu kavram bütün insanlarca sahip olunması beklenen ideal hakların tamamını ifade etmede kullanılmaktadır. $\mathrm{Bu}$ haklar, güçlü olanın karşısında zayıf olanı, ahlaki kurallar ve yasal düzenlemelerle korunmaya çalışır.

Modernleşme sürecinde çocuk ve çocukluk kavramlarında önemli gelişmeler olmakla birlikte çocuk hakları konusunda I. Dünya Savaşı öncesi Batı'da kayda değer bir girişimin olmadığı söylenebilir. Uzun asırlar boyu Batı'da yetişkinler, çocukların duygularını anlayıp paylaşmada çok istekli olmadıkları gibi davranışlarının, çocuğun gelişimini nasıl etkilediği konusunda da açık bir düşünceye sahip değillerdi. Günümüzde "çocuk istismarı" veya "ihmali" olarak tanımlanan pek çok davranışın geçmiş yüzyıllarda çok olağan olduğuna inanılmaktaydı (Gander, Gardiner, 2004: 29). Ortaçağ ve sonrasının manastırları ve kolejlerinin iyi Hristiyan yetiştirmeyi amaçlayan dinsel otoritesinin yerini modern dönemde yeni bir otorite olarak devlet almaya başladı (Bumin, 1983: 8). Bu dönemde Batı'da çocuğun çok yönlü yetiştirilmesi ve ekonomik hayata hazırlanması konularında devletler inisiyatif üstlenmeye başlamıştı. Ailede okula hazırlanan çocuğu okul orduya ve fabrikaya hazırlıyordu (Bumin, 1983: 10). Modernlik; rrk, kültürel etniklik gözetmeksizin tüm çocukların evrensel bir çocuk doğasına sahip olduğuna inanmaktaydı (Elkind, 1994: 15). Tarihin, seçkinlerin öyküsünü anlatmaktan öte bir şey olması gerektiğini düşünen yeni sosyal tarihçiler sınıf, ırk, cinsiyet, din, kültür ve yaşına bakılmaksızın tüm insan kümelerinin yaşantılarını kuşatan bir tarih yazma çabasına girmişlerdir (Tan, 1994: 15). Modern çocuk paradigmasının da katkısıyla çocukların yetişkinlerden farklı olduğu, özel bir bakım ve korumaya muhtaç olduğu, zihinsel ve bedensel gelişim döneminin onun gelecekteki tüm hayatı üzerindeki belirleyici etkisi olduğu daha iyi anlaşıldı. Dolayısıyla farklı haklara sahip olduğu gerekçesiyle hakların açıkça tanınması gerektiği düşünceleri gelişmeye başladı. Bunun bir sonucu olarak çocukların insan hakları temelinde daha özel şartlarla korunması gerektiği bir ihtiyaç olarak belirdi. Böylece Batı'da çocuk hakları kavramı, I. Dünya Savaşının yıkıcı sonuçları ve çocuklar üzerinde bıraktığı fiziksel ve psikolojik etkiler sonrası gündeme gelmiştir. Bu konuda ilk girişimin, 1917 Ekim Devriminin ardından Proletkult isimli sosyalist kültür örgütünün Moskova Şubesi tarafından "Çocuk Hakları Bildirgesi" ismiyle kaleme alınan metin olduğu belirtilmektedir (Akşam Gazetesi, 2018). Yine Leh eğitimci Janusz Korczak'ın, I. Dünya Savaşı yıllarında çocukların yaşadığı sıkıntılar üzerine 1919 yılında yazdığ "Bir Çocuğu Nasıl Sevmek Gerekir" adlı eserin (Gören, 2017: 44) bu alandaki ilklerden olduğu, çocuk haklarının bu eserle birlikte oldukça görünür bir hal aldığı ileri sürülmektedir. Milletler Cemiyeti tarafindan oluşturulan diğer metinlerle bu sürecin devam ettirdiği görülür.

Modern çağla birlikte çocukluğun kaderinde dünya çapında meydana gelen değişmelerin Türk çocukluk algısını da önemli ölçüde etkilediği söylenebilir. Türk toplumunda, geçmişten günümüze çocuk hakları konusu her zaman önemsenmiştir. Çocuğu, ailenin tabii üyesi olarak gören Türk töresi, bakımı, korunması ve eğitimi görevlerini de büyük ölçüde aileye yüklemiştir (Ögel, 2000: 69). Töre, bir yandan çocuğun aile içindeki görev ve sorumluluklarını gösterirken diğer yandan da ailenin çocuğa karşı görevlerini belirlemiştir (Akyüz, 2012: 22).

İslam'ın kabulünden sonra Türk çocukluk anlayışında bazı değişiklikler olduğu görülür. İslam'ın temel kaynaklarında çocuk konusuna özel vurgu yapılması, bu konudaki duyarlılığın sürekliliğini sağlamıştır. Çocukluk kavramı, İslam'ın temel kaynakları olan Kuran ve Sünnet'te ayrıntılı bir şekilde işlenmiş, çocuk buluğ yaşına kadar "mükellef' sayılmamıştır. Bu nedenle, İslam düşünürleri ilk dönemden itibaren çocuğu ve çocuk haklarını eserlerinde derinlemesine işlemişlerdir (Canan, 1980: 127). Örneğin Gazali, "çocuk hakları" konusunu Kimya-i Saadet adlı eserinde müstakil bir başlık altında işlemiştir (Gazali, 1979: 302-303). Bu yeni dönemde çocuğun bakımı, eğitimi ve korunması büyük ölçüde aileye bırakılırken (Akyüz, 2012: 23) çocuğun aynı zamanda "Vediatü'llah" (Allah'ın emaneti) (Gazali, 1996: 101) olduğu gerekçesiyle aileye kutsal bir 
sorumluluk yüklenmiştir. Eserlerin pek çoğunda çocukların ailedeki görev ve sorumluluklarından söz edilirken aynı zamanda ana-babaların çocuklara karşı görevleri de sayılıp dökülmüştür. Müslüman eğitimcilerin eserlerinde çocuk haklarına ilişkin yaptıkları vurgular ve açıklamalar, Türk toplumunda konuya olan duyarlılığı oldukça eskiye götürmektedir.

Türkiye'de çocuğa lâyık olduğu önemin verilmesi ve onu bedensel, ruhsal ve ahlâkî tehlikelere karşı korumak amacıyla kurumların oluşturulmasına 19. yüzyılda başlanmıştır (Akyüz, 1999: 495). Padişah II. Mahmut tarafindan yayımlanan 1824 tarihli "Talim-i Sıbyan Fermanı" çocuk hakları alanında bilinen ilk resmî belgedir. II. Mahmut'un bu fermanı o dönemde Batıda yaşanan çocuk ve çocukluk algısının oldukça ilerisinde bir muhtevaya sahiptir. Daha sonra Sultan Abdülmecit'in 1845 'te Bab-1 Ali'ye gidip Sadrazam ve tüm vekillere hitaben okuttuğu, eğitimin geliştirilmesiyle ilgili bir fermanda çocuğun eğitim hakkına dikkat çekilmiştir. Bu ferman 1846'da kurulan Meclis-i Maarif-i Umumiye tarafından hazırlanıp Sultan Abdülmecit'in bir iradesi olarak Nisan 1847 tarihinde ilköğretimle ilgili bir Talimatname olarak yayımlanmıştır (Akyüz, 1994: 1). Bu ferman da çocukluk algısına ve çocukların eğitimine ilişkin çok önemli belirlemeler ve hükümler içermektedir. Daha sonra savaşlar ve ekonomik sıkıntılarla yaşanan felaketlerden en fazla etkilenen çocuklar olduğu için çocukların gelişmesi ve korunması için çeşitli tedbirler alınmıştır. Çok sayıda yasal düzenlemenin yapıldığı bu dönemde çocukların korunmasıyla ilgili nizamnamelerin çıkarıldığını görülür. Örneğin, yetim mallarının korunmasıyla ilgili olarak çıkarılan ilk nizamname, Aralık 1851 tarihli "Eytam Nizamnamesi"dir (Akyüz, 1999: 495). Dönemin çocuklarını korumaya yönelik bir diğer önemli gelişmesi de Mithat Paşa tarafından ilki 1863 yılında kurulan ve daha sonra sayıları 15'i aşan çocuk 1slahhaneleridir. Bu kurumlar, yetim ve öksüz veya aileleri kendilerine bakamayacak kadar fakir olan Müslüman ve gayri müslim çocuklara temel eğitim vermek ve meslek kazandırmak amacını taşımaktaydı (TDV, 1999: 190). Yine yetim çocukların eğitim ve korunmasına yönelik önemli kurumlar arasında, 1873'te açılan "Darüşşafaka" ile 1895'te açılan ve kimsesiz çocukların da korunmasını amaçlayan "Darülaceze" (Akyüz, 1999: 495) sayılabilir. Meşrutiyet döneminde Trablusgarb (1911) ve Balkan (1912) savaşları sonucunda çoğalan şehit yetimlerini korumak amacıyla kurulan "Darüleytamlar" benzer şekilde kimsesiz çocukların korunmasına dönük yaygın kurumlardır (Akyüz, 1999: 496).

$\mathrm{Bu}$ süreçte çocuk haklarına ilişkin müstakil eserler yayımlandığı gibi (Bandırmalızâde, 1318), 1869 tarihinden itibaren çok sayıda çocuk dergisi yayımlanmıştır. Bu dergilerde özellikle II. Meşrutiyet yıllarında çocuk hakları konusu, işlenmiş, hatta 1914 yılında çocuk haklarıyla alakalı sekiz sayfa halinde müstakil haftalık bir dergi yayımlanmıştır (Gurbetoğlu, 2007). Bütün bu düzenleme ve uygulamalar, çocuk hakları konusunda Osmanlı'da yaşanan gelişmelerin göstergelerindendir.

\subsection{Uluslararası Hukuk ve Çocuk Hakları}

İnsan haklarının uluslararası alanda güvenceye kavuşması Birleşmiş Milletler ve Avrupa Konseyi gibi uluslararası kuruluşların konuya gösterdiği ilgiyle sağlanmıştır. Bu konudaki gelişmeler aynı zamanda çocuk hakları alanında da gelişmelere kaynaklık etmiştir.

Çocuk haklarına ilişkin uluslararası düzeyde ilk belgenin, 1924 yılında Milletlerarası Çocuklara Yardım Birliği öncülüğünde, "Cenevre Çocuk Hakları Bildirgesi" adıyla hazırlanan, çocukların korunmasına yönelik sözleşme olduğu kabul edilir (Akyüz, 1999: 494). Bu bildirgede yayımlanan beş maddeyle; muhtaç çocukların doğal gelişimlerinin sağlaması, eğitimleri, beslenmeleri, tedavi edilmeleri, sslah edilmeleri, yardım ve korunma ihtiyacı durumunda öncelikleri, istismara karşı korunmaları gibi hususlara vurgu yapılmıştır. Söz konusu bildirge Türkiye tarafından 1928 y1lında kabul edilmiştir. Daha sonra 1936 tarihinde Türkiye'nin de dahil olduğu, Balkan ülkelerindeki çocukları korumaya yönelik kuruluşların katılımıyla toplanan Birinci Balkan Kongresi ile 1938'de toplanan İkinci Balkan Kongresi, çocukların korunması ve çalışma dönem ve şartları 
üzerinde yoğunlaşmıştır (Akyüz, 2012: 38). Bu girişimler bölgesel olmakla birlikte uluslararası çalışmalardan kabul edilebilirler.

Özellikle II. Dünya savaşı sırasında yaşanan olumsuzluklar yeniden dikkatleri insan hakları konusuna yöneltmişti. Savaş sonrası 1948 yılında konu BM Genel Kurulu'nda tartışıldı ve şartları iyileştirecek "İnsan Hakları Evrensel Bildirgesi”" kabul edildi (Kepenekçi, 2000: 2). Bu bildirge doğal olarak çocukların hak ve özgürlüklerini de koruma altına aldı. Bununla birlikte çocukların ruhen ve bedenen korunmaya muhtaç olması nedeniyle ayrı bir düzenlemeye ihtiyaç duyuldu. Özellikle İkinci Dünya Savaşı ile daha fazla şiddet ve felakete maruz kalan çocukların durumu bu alanda yeni tedbirlerin düşünülmesini ihtiyaç haline getirmiști. Bu amaçla, 1924 tarihli Cenevre Bildirgesi geliştirilerek, ilave edilen beş madde ile oluşturulan on maddelik "Çocuk Hakları Bildirgesi” BM Genel Kurulu'nda 1959'da kabul edildi.

BM'de 1948'de kabul edilen “İnsan Hakları Evrensel Bildirgesi”nde yer alan ilkesel, özlü ifadeleri açıklığa kavuşturmak amacıyla BM'ye üye ülkeler ilave sözleşmeler oluşturmuşlardır. Bunlardan çok bilinenleri, "Kişisel ve Siyasal Haklar Uluslararası Sözleşmesi (1966)", "Ekonomik, Toplumsal ve Kültürel Haklar Uluslararası Sözleşmesi (1968)" gibi ilave metinlerdir. Benzer şekilde Avrupa Konseyi tarafından hazırlanan "Avrupa İnsan Hakları Sözleşmesi (1950)" insan hak ve özgürlüklerini etkin bir şekilde korumaya yöneliktir. Bu metin bir yandan insan haklarının korunmasını hedeflerken aynı zamanda uluslararası yarg1 niteliğinde bir hukuk mekanizmas1 oluşturmuştur. Adı geçen sözleşme Türkiye'de 10 Mart 1954 tarih ve 6366 sayılı yasayla kabul edilip onaylanmıştır. (Kepenekçi, 2000: 3).

Bütün bu sözleşmeler, dünyada insan hakları konusunda yaşanan olumsuzlukların önüne geçilmesine dönük çabaların somut ürünleridir. Bunlar aynı zamanda çocuklara yönelik ihlallerin önlenmesine de önemli katkılar sunmuştur. Ancak, yetişkinlerden çok farklı olarak özel bir ihtimama muhtaç olan çocukların haklarını korumaya dönük çalışmalara da özellikle ihtiyaç duyulmaktaydı. 20 Kasım 1959 tarihli "Birleşmiş Milletler Çocuk Hakları Bildirgesi” o zamana kadar alanında en gelişmiş metindi (Akyüz, 2012: 38). Ancak bu metin, zamanla dünyada meydana gelen sosyoekonomik ve siyasal gelişmelerle, çocuğun haklarının korunmasında yeterli olma vasfını kaybetmişti. Mevcut metinde, bağlayıcı hükümlerden çok, iyi niyetli temenniler hakimdi. Bu durum daha bağlayıcı bir metne ihtiyaç gösteriyordu. Bu amaçla 1978'lerde BM nezdinde başlatılan çalışmalar, 20 Kasım 1989 tarihinde neticelenmiş, elli dört maddelik "Birleşmiş Milletler Çocuk Haklarına Dair Sözleşme" adıyla BM genel kurulunda kabul edilmiştir (Akyüz, 2012: 40). Türkiye aynı yıl, adı geçen sözleşmeye ilk imza koyan devletler içinde yer almış ve sözleşmeyi, 1995 tarihinde 4058 sayılı kanunla iç hukuk kuralına dönüştürmüştür (Polat. 2008: 149).

Sözleşmenin birinci maddesinde 18 yaşından küçük olan her insan çocuk olarak kabul edilmiştir. Bu kabul, taraf devletlerin ortak kabulü olup, uygun şekilde iç hukuklarına yansıtılmıştır. Örneğin 5237 sayılı Türk Ceza Kanunu'nun 6. maddesinde çocuk ifadesinden "18 yaşını doldurmamış kişi” anlaşılacağı belirtilmiştir (TCK, 2004). Yine 5395 sayılı Çocuk Koruma Kanunun 3. maddesinde, "daha erken reşit olsa bile 18 yaşını doldurmamış kimse çocuk sayılır" denilmektedir (ÇKK, 2005). Bu maddeler Çocuk Hakları sözleşmesini birinci maddesinin Türkiye'nin iç hukukuna yansımalarıdır. Diğer maddeler de uygun şekilde Türk hukukuna yansıtılmıştır.

\section{3. Çocuk Hakları Sözleşmesi'nin Temel İlkeleri}

Birleşmiş Milletler Çocuk Haklarına Dair Sözleşme'nin ilk maddesi, sözleşme amaçları açısından çocuğu, "18 yaşından küçük insan" olarak tanımlamaktadır. Söz konusu sözleşme üç bölümden oluşmaktadır. İlk kırk bir maddeden oluşan birinci kısım sözleşmenin hükümlerini, ellinci maddeye kadar olan ikinci kısım, katılımcı devletlerin görevlerini, son dört madden oluşan üçüncü kısım da genel hükümleri ifade etmektedir. Sözleşme hükümlerinde çocuk hakları; yaşama, gelişme, katılım ve koruma gibi dört temel alanı kapsamaktadır. 
Yaşama Hakkı: Her çocuk, en temel insan hakkı olan yaşama hakkına sahiptir. Çocukların yaşama hakkına saygı gösterilmesi ve ayrımcılığa karşı korunmasını ifade eder. Tüm çocukların insani hak ve özgürlüklere eşit biçimde sahip olmalarını hükme bağlayan maddeleri içermektedir. Sözleşmede tüm çocukların bu haklardan özgürce ve eşit olarak yararlanmalarına engel teşkil edecek herhangi bir ayrım, kısıtlama, dışlama gibi fiillerin önlenmesine dönük maddeler yer almaktadır. Sözleşmenin 2. maddesi ayrımcıllğı önlemeye dönüktür. Çocukların fiziksel ve ruhsal bütünlüğünün korunması, fizik ve ruh sağlığını olumsuz etkileyecek çeşitli etkenlere karşı korunmasına yönelik maddeler bu alanla ilgilidir. Sözleşmenin 6. maddesinde çocuğun yaşama hakkına ve bu konuda devletin görevine vurgu yapılmıştır.

Gelişme Hakkr: Sözleşmede çocuğun gelişimi kavramı çok yönlü olarak işlenmiştir. Gelişme hakkı, eğitim hakkını da içeren çok yönlü bir haktır. Bu bakımdan çocuğun gelişme hakkı; bedensel, duygusal, zihinsel, sosyal, kültürel, ekonomik, hukuki, ahlaki yönlerden topyekûn gelişimini ifade eder. Çocuğun gelişme hakkı, sözleşmenin 6. maddesinde yaşama hakkıyla birlikte ele alınmış, çocuğun yaşama ve gelişimini güvence altına alma görevini devlete yüklemiştir. Devletler çocuklara bu hakkı daha çok eğitime ulaşım imkanlarını sağlayarak ve eğitimin niteliğini artırarak güvence altına almaktadır.

Sözleşmenin 18. Maddesi, çocuğun yetiştirilmesi ve gelişmesinin sağlanmasında anababayla birlikte devlete de sorumluluk yüklemiştir. 28. ve 29. maddeler çocuğun eğitim hakkını kullanmasında doğrudan devletin yükümlülükleriyle ilgilidir.

Katılım Hakkı: Sözleşmede çocuğun haklarını kullanmada aile, okul gibi sosyal çevrelerde kabul ve saygınlık görmesine, söz ve katılım hakkının bulunmasını sağlamaya yönelik maddeler bu alanla ilgilidir. Sözleşmenin 12, 13, 15. maddeleri çocuğun, ailede, okulda ve toplumsal hayata aktif katılımını, şahsını ilgilendiren her konuda görüşlerini serbestçe ifade edebilmesini güvence altına alır. Aynı şekilde 28. maddesi, okul disiplinin insan onuruna uygun olması gerektiğini, 38. maddesi de hiçbir çocuğun insanlık dışı, aşağılayıcı muameleye ve cezaya tabi tutulamayacağını ifade eder.

Korunma Hakkı: Sosyal yardım kuruluşları, mahkemeler, yasama organları gibi çocuğun hayatıyla ilgili bütün faaliyetlerin düzenlenmesinde en yüksek yararının göz önünde bulundurulmasıdır. Çocuğun bedensel, duygusal, zihinsel, sosyal, kültürel, ekonomik, hukuki, ahlaki yönden tüm yararlarının gözetilmesidir. Çocuğun güvenliğini sağlamaya yönelik önlemler de bu sınıftandır. Sözleşmenin 3. maddesi, çocuğa yönelik politikaların belirlenmesinde, kararların alınmasında çocuğun yüksek yararının yol gösterici olmasını hükme bağlar. Yine sözleşmenin 19, $32,33,34,35,36$ ve 37 . maddeleri, çocukları her türlü şiddet ve sömürüden korumaya yönelik hükümler içermektedir.

Çocuk hakları sözleşmesindeki genel hükümler bu bağlamda önemli olduğundan burada kısaca değerlendirilmiştir. Ancak bu çalışmanın konusu olan "Talim-i Sibyan Fermanı" bu haklardan "çocuğun eğitim hakkı" ve "çocuk istismarının önlenmesi” konusuyla doğrudan ilişkilidir. Bunlar da çocuğun; "gelişme" ve "korunma" hakkıyla alakalıdır. O nedenle özellikle bu iki hususun ayrıca açıklanmasına ihtiyaç vardır.

\section{1. Çocuğun Eğitim Hakkı}

Çocuğun eğitim hakkı onun bir anlamda hayata tutunma hakkı olarak son derece önemlidir. Eğitim ve ekonomi, birbirini doğrudan etkileyen çok önemli iki kurumdur. Bunlar aynı zamanda ferd ve toplum hayatını da yakından etkilemektedir. Eğitilmiş insan gücünün üretim kabiliyetinin hem kendisi hem de toplum adına ne gibi yararları olduğu eskilerin "bedihi" dediği tartışılmayacak kadar açık gerçeklerdendir. Ülkelerin kalkınması, bireylerin huzurlu ve müreffeh olması, harcadıkları emek, zaman ve kaynaklardan azami düzeyde yararlanabilmeleri, araç ve imkanlarını azami derecede kullanabilme becerileriyle doğrudan ilişkilidir. Eğitim sadece ülkede okuma yazma bilen insanların sayısını artırmaktan ibaret değildir. Eğitimin bunlarla birlikte odaklanması gereken ana nokta 
çocuklarda bilişsel, duyuşsal ve psikomotor gelişmeleri sağlayacak araç ve imkanları kullanarak onlarda hayatın maddi-manevi her türlü ihtiyacını karşılayabilecek beceri ve alışkanlıkları ortaya çıkarmak olmalıdır. Bu açıdan temel eğitimin amacı, bütün çocukları aynı eğitim sürecinden geçirerek onlarda ortak bir ruhun gelişmesini sağlamaktır. Nüfus hareketliliği nedeniyle köy, kasaba ve şehirlerde ortak programla ortak duygu ve düşüncenin geliştirilmesi bu öğretim kademesinin amaçlarındandır.

Yakın geçmişe kadar Türkiye'de ilkokulların köylerde üç yıl, şehirlerde ise beş yıl olması, orta tahsil veren kurumların büyük ilçeler ve illerde bulunması, lise düzeyindeki okulların da ancak bölgeler için söz konusu olması eğitimden beklenen, çocuklarda ortak bir ruh geliştirmesi amacinı olumsuz etkileyen en temel nedenlerdendir. Günümüz dünyasında aynı nedenlere bağlı olarak ortaya çıkan sorunlar, küresel dünya şartlarında tüm dünyayı etkileyecek sonuçlar doğurabilmektedir.

Bu özelliği sebebiyle, eğitim hakkı başta 1948 İnsan Hakları Evrensel Bildirgesi olmak üzere, pek çok uluslararası bildirge ve sözleşmede yer almıştır. Bu hak, 1989 tarihli Çocuk Haklarına Dair Sözleşme'nin 28. maddesiyle de güvence altına alınmıştır. Bu madde bir yandan taraf devletlerde çocuklara eğitim hakkının tanınmasını hükme bağlarken, diğer yandan ücretsiz, zorunlu temel eğitimin sağlanmasında, ortaöğretimin genel ve mesleki olmak üzere çeşitlendirilmesinde ve bunların tüm çocuklara açık bulundurulmasında yükümlülükler getirmiştir. Bununla birlikte sözleşme, yetenekleri doğrultusunda tüm çocukların yüksek öğretimden yararlanması konusunda taraf devletlere uygun imkanları oluşturma görevi yüklemektedir.

Aynı sözleşme, taraf devletlerden, çocukların bilişsel, duyuşsal, devinişsel yönden geliştirilmesini sağlayacak, duygusal, moral gelişimlerini güçlendirecek nitelikli eğitim ortam ve imkanlarının hazırlanmasını talep etmektedir. Sözleşmenin 29. maddesi, çocuğun kişiliğinin, zihinsel ve fiziksel yeteneklerinin istidadına uygun olarak en üst düzeye kadar geliştirilmesini istemektedir. Çocuğun, temel insan haklarına ve özgürlüklere saygıll, hoşgörülü, her türlü ayrımcıllktan uzak, tüm canlılara karşı dostluk ruhuyla yetiştirilmesi temel hedef olarak tasvir edilmiştir. Aynı şekilde tüm çocukların hem kendilerine hem de topluma karşı sorumluluklarının bilincinde, yararlı bir birey olarak yetiştirilmesi beklenmektedir.

\section{2. Çocuk İhmal ve İstismarının Önlenmesi}

Çocuğun ihmali ve istismarı konusu çocukluk kadar eski bir konudur. Çocuklar, haklarının farkında olma ve bunları talep etme yetkinliğine sahip olmadığından bu konu yetişkinlerin onlar hakkındaki insaf ve tasarruflarıyla şekillenmiştir. Tarih boyunca her toplumun, çocuğun ihmal ve istismarını önlemeye dönük birtakım tedbirler aldığına şüphe yoktur. Bununla birlikte çocukların ihmal ve istismarı, günümüze kadar en önemli çocuk sorunlarından biri olmaya devam etmiştir.

İhmal kavramı, çocuğun hakkına saygı gösterilmemesini ve sahip olduğu hakları kullanmasında ona yardımcı olmada duyarlı davranılmamasını ifade eder. İstismar kavramı ise, sömürü kavramından türetilmiştir. Güçsüzlüğü, yetkin olmayışı ve kendi zararına ve yararına olacak şeyleri bilemeyişinden dolayı yetişkinlerce onun haklarının ihlal edilmesini ifade eder. Çocuk istismarı kavramından kastedilen; çocuğun bedensel, zihinsel, sosyal ve ahlaki gibi çeşitli yönlerden gelişimini zedeleyen, önleyen veya olumsuz etkileyen tutum ve eylemlerdir. Çocuğun kişiliğine zarar verecek her türlü sözel, fiziksel hareket istismar olarak kabul edilmektedir (Polat, 2008: 154) Toplum tarafından benimsenen genel ahlak kurallarına uygun olmayan tutum ve davranışlar da bu cümledendir. Bu tutum ve eylemler, başta anne-baba ve yetiştiriciler olmak üzere çoğunlukla yetişkinler tarafından sergilenmektedir.

Çocuklara yönelik ilk uluslararası belge olan 1924 tarihli "Cenevre Çocuk Hakları Beyannamesi", çocuğun korunması, beslenip gelişmesi, eğitimi, sağlı̆̆ı, barış ruhu içinde yetiştirilmesi yanında her türlü istismara karşı korunmasını da prensip olarak benimsemiştir. Bununla birlikte gelişen dünya şartları, bu prensiplere ilişkin temennilerin yeterli olmadığını gösterdi. 
Özellikle II. Dünya Savaşında çok büyük bir çocuk kitlesinin büyük mağduriyetler yaşaması, dikkatleri çocukların korunmasına yönelik tedbir arayışlarına yöneltti. 1959 tarihinde "Birleşmiş Milletler Çocuk Hakları Beyannamesi" adıyla yayımlanan uluslararası metinde "çocukların istismarının önlenmesi” hakkında ilkeler belirlenmiştir. Taraf devletlerce kabul edilen bu ilkelerin bağlayıcı bir yönü bulunmamaktadır.

\section{Osmanlı'da Temel Eğitim}

Eğitim hakkı, çocukların çok yönlü gelişimini sağlama açısından önemli olduğu kadar, ihmal ve istismarının önlemesinde de anahtar konumundadır. O nedenle eğitim sistemlerinin nitelik ve nicelikleri o toplumda çocukluk olgusunun durumunu sergileyen önemli göstergelerdendir. $\mathrm{Bu}$ bakımdan "Talim-i Sıbyan Fermanı”nın önemini tam olarak kavrayabilmek için Osmanlı'da temel eğitimi kısaca hatırlamakta yarar vardır.

Okulların Kuruluşu: Osmanlı'da temel eğitim kurumları çeşitli adlarla anılmakla birlikte* genellikle "sıbyan mektebi" adıyla bilinirler. Bu mektepler Osmanlı'da şehirlerdeki en kenar mahallerden en ücra köylere kadar yayılmıştı. Daha çok bir caminin yanında veya bitişiğinde yer alırlardı. Bu okulları devlet adamları ya da varlıklı kişiler vakıf yoluyla kurarlar ve giderleri de vakıf gelirleriyle karşılanırdı. Köy ve mahallelerde genellikle halk elbirliğiyle mektep yapar, öğretmen maaşı dahil her türlü giderini de karşılardı (Akyüz, 2019: 88).

Öğrenciler: Okula başlamanın belli bir yaşı bulunmamakla birlikte kız ve erkek çocuklar genellikle 4 yaşından buluğ çağına kadar bu okullara devam eder, birlikte eğitim görürlerdi. Okula başlamanın belli bir dönemi de yoktu. Çocuklar yılın herhangi bir döneminde okula başlayabilirdi. Okula gitme konusunda herhangi bir zorunluluk da yoktu. Çocukların okula devamı, tamamen velilerin talebi ile gerçekleşmekteydi. O nedenle gerek velileri ve gerekse çocukları okula devama isteklendirmek için "Bed-i Besmele" gibi özendirici törenler düzenlenmekteydi (Akyüz, 2019: 89).

Öğretmenler: Sıbyan mektebinde görev alacak öğretmenlerin niteliği konusunda herhangi bir belirleme mevcut değildi. Öğretmenler genellikle hemen yakındaki caminin de imamlık görevini yürütmekteydi. Öğretmen görevlendirme işlemi de ilgili vakıf yahut mahalle veya köy yöneticilerince gerçekleştiriliyordu. Öğretmen olarak genellikle medrese mezunu yahut medresede bir müddet okumuş kimseler tercih edilmekteydi. Bununla birlikte temel dini bilgilere vakıf olan, çocuklara okumayı ve temel dini bilgileri öğretebilecek derecede bilgi sahibi olanlar da öğretmen olarak görevlendirilebiliyordu. Her ne kadar Fatih döneminde Ayasofya ve Eyüp medreselerinde sıbyan mektebi hocası olacaklar için ayrı bir program uygulanmış olsa da bunun genel geçer bir zorunluluk olmadığı ve uzun süre devam etmediği anlaşılmaktadır (Akyüz, 2019: 92).

Program: Sıbyan mekteplerinin tamamı için geçerli olacak, belirlenmiş özel bir program mevcut değildi. Devlet adamlarının veya vakıfların açtığı sıbyan mekteplerinin programına ilişkin vakıf senedinde açıklayıcı hükümler ve bu çerçevede bir programın yer aldığı olmuştur. Bu durum tüm sıbyan mektepleri için geçerli değildir. Genellikle halkın kendi imkanlarıyla açtıkları okullarda programlar daha çok görevli öğretmenin bilgi ve beceri düzeyine bağlı olarak değişmekteydi. Bununla birlikte genellikle gündelik hayatta ve ibadetlerde gerekli olan ve "zarurat-1 diniye" denilen temel dini bilgilerin öğretimi programların özünü oluşturuyordu. $\mathrm{Bu}$ anlamda tüm sıbyan mekteplerinin vazgeçilmez temel dersleri Kur'an ve temel dini bilgilere dayalı derslerdi. Eğitim tarihçisi Yahya Akyüz, sıbyan mekteplerinde Kur'an öğretiminin vazgeçilmez temel ders olmasını İbni Haldun'dan yaptığı nakille açıklar. İbni Haldun'a göre temel eğitimle çocukların kalbine küçük yaştan itibaren Kur'an sevgisini yerleştirmek gerekir. Daha sonra öğretimlerini sürdürüp sürdürmeyecekleri bilinmediğinden, çocuklukta böyle bir sevgiyi kazanmaları önemli görülmüştür

\footnotetext{
* Osmanlılarda geleneksel ilköğretim kurumu olan sıbyan mektebi; Dâru't-ta'lim, Dâru'l-'ilm, Muallimhâne, Mekteb, Mektephâne, Mahalle Mektebi, Taş Mekteb, Mekteb-i ibtidaiye gibi muhtelif adlarla anılmaktadır. Bu konuda ayrıntılı bilgi için bkz (Akyüz 2019:88).
} 
(Akyüz, 2019: 88). Bu temel derslerin dışında basit matematik, tarih, coğrafya, adabı muaşeret kuralları gibi konuların da bazı sıbyan mekteplerinin programlarında yer aldığı olmuştur. Bu konuda, görevli öğretmenin yetkinliği belirleyici olmuştur.

\section{Yöntem}

$\mathrm{Bu}$ çalışma nitel araştırma yöntemine dayalı doküman incelemesi deseninde yapılmıştır. Çalışmada II. Mahmut'un 1824 tarihli “Talim-i Sıbyan Fermanı” temel kaynak olarak kullanılmıştır. Fermanın orijinal belgesinin mevcut olup olmadığı bilinmemektedir. Tarafımızca Başbakanlık Osmanlı arşivinde yapılan araştırmada ilgili fermana ulaşılamamıştır. Arşiv yetkililerinin umudu, henüz tasnif edilmemiş milyonlarca belge arasında bulunabileceği yönündedir. Bu bakımdan araştırma konusu fermanın tam metni Ahmet Cevdet Paşanın "Tarih-i Cevdet" adlı eserinin Osmanlıca aslından bulunarak incelenmiş̧tir. Araştırma konusu fermanın içeriğiyle yapılacak değerlendirmeye esas olmak üzere çalışmada, kısaca çocukluğun tarihsel gelişimine, çocuk hakları ve hukuk gibi konulara temas edilmiş, bu anlamda "Çocuk Hakları Sözleşmesi"nin temel ilkeleri üzerinde durulmuştur. Bir durum tespiti açısından Osmanlı'da temel eğitim konusu da kısaca özetlenmiştir. Daha sonra fermanın tam metni Osmanlıca aslından çevrilerek verilmiştir. Daha sonra ferman; özellikleri, gerekçesi ve vurguladığı hususlar itibariyle ayrıntılı olarak incelenmiş, "temel eğitimin zorunluluğu" ve "çocuk hakları" açısından değerlendirilmiştir. Çalışmada, araştırma ve yayın etiği ilkelerine uyulmuştur.

\section{Talim-i Sıbyan Fermanı}

Türk eğitim tarihinde ilköğretim zorunluluğu getiren ilk yasal belge niteliği taşıyan 1824 tarihli bu fermanın, II. Mahmut'un çocukların eğitimi konusunda gösterdiği duyarlılığın bir göstergesi olduğunda şüphe yoktur. Zaten adı geçen ferman, araştırmacılar tarafindan bu yönüyle çeşitli açılardan değerlendirilmiştir. $\mathrm{O}$ tarihe kadar geniş halk kitlelerinin eğitiminde aktif görev üstlenmeyen devlet, bu alanda boşluğu doldurmak üzere kurulmuş vakıfların denetleme ve düzenlemesiyle yetinmiştir. Çocukların eğitimi konusunda ailelerin talebi, asırlarca bireysel girişimlerce veya vakıflara karşılanmıştı. Bu ferman çocukların temel eğitimi konusunda devletin ilk defa aktif olarak devreye girmesinin bir ifadesidir. Hiçbir ön hazırlık yapılmadan, yapısal düzenlemelere gidilmeden, öğretmen ihtiyacı, eğitim araç gereç ve finansmanının hesabı yapılmadan böyle bir fermanın yayımlanmış olması çeşitli yönlerden değerlendirilip eleştirilere tabi tutulmuştur. İstanbul'daki Müslüman çocukları için sıbyan mekteplerine devamı zorunlu hale getirmeyi amaçlayan bu belgenin amir hükmünün taşradaki sıbyan mektepleri için de geçerli olması hedeflense de bu konuda başarı sağlanamadığı bilinmektedir. Hatta ferman gereği okullaşmanın İstanbul için bile hedefine ulaşma durumu tartışılmıştır. Bu tartışmalarla birlikte bu fermanın anlamı, ilköğretimi zorunlu hale getirerek bütün topluma yayma amacı taşıyan çok önemli bir yenilik oluşunda düğümlüdür.

Ferman, içeriği itibariyle aynı zamanda çocuk haklarını korumaya yönelik çok önemli bir belge niteliğindedir. $\mathrm{Bu}$ yönüyle Türk çocukluk tarihi konusunda önemli olduğu kadar dünya çocukluk tarihi açısından da son derece önemli yasal belgelerden biridir. İşte çok bilinen ve çok tartışılan bu ferman, çocuk hakları konusunda içerdiği önemli hükümler yönüyle adeta gözden kaçmış, bu özelliğiyle günümüze kadar herhangi bir değerlendirmeye de tabi tutulmamıştır.

\subsection{Talim-i Sıbyan Fermanı'nın Tam Metni}

\section{Talim-i Sıbyan Hakkında Ferman-1 Âlî}

Cümleye malumdur ki, ümmet-i Muhammed'denim diyen kâffe-i ehl-i İslam'a göre ibtida şerâit-i İslâmiye'yi ve akaid-i diniyesini öğrenip bilmek badehû iktisâb-1 maişet (geçimlik kazanç) için kanği (hangi) dirliğe sülük (mesleğe girmek) edecek ise etmek. Velhasıl her bir şeyden evvel zaruriyyat-1 diniyeyi öğrenmekliği umur-i dünyeviyenin cümlesine takdim eylemek lâzım iken; bir zamandan beri ekseri nâs (insanlar) analarının ve babalarının seyyiesi (günahı) olarak kendileri 
kaldıkları misillû, evladlarının cahil kalmasını düşünmeyerek ve Rezzak-ı âlem olan Hak Sübhanehu ve Teâlâ Hazretlerine adem-i tevekkül ile hemen akça (para) kazanmak daiyesine (hırs) düşerek, çocukları beş altı yaşına vardığı gibi mektepten alıp ehl-i hiref (sanatkâr) yanına şakirtliğe (çırak) verdiklerinden, o makule (tür) sabîler küçükten cehaletle büyüyüp sonra dahi okuyup öğrenmeye heves etmediklerine binaen, vizr-u veballeri (günah) analarının ve babalarının boynuna olup yevmi kıyamette bir taraftan bunlar, giriftar-1 mesuliyet ve bir taraftan kendileri, duçar-1 hızy-u nedâmet (utanç ve pişmanlık) olacaklarından başka, maaz Allah'u Teâlâ zamâne-i cehâlet istiâbıyla (zamanın cehaletine tutularak) ekser halk diyanetten bî haber olduklarından, bu keyfiyet nusretsizliğe (yardımın kesilmesine) sebeb-i müstakil olup, 'asemenallahu Teâlâ (Allah korusun) böyle giderse min kibeli'r-Rahman, (Rahman tarafından) terbiye-i şedîdeyi müstelzim olacağı (şiddetli bir terbiyeyi gerektireceği), erbab-1 basirete zâhir ve hüveydâ (apaçık) olmaktan nâşi (dolayı), ibâd-1 Müslimini o misillû dünya ve ahiret ukûbatından (ceza) tahlis (kurtarmak) ve sıyanet (koruma) lazım gelmekle, imdi emr-i dinde şerm-u istihya (utanç ve haya) câiz olmadığına binaen, şimdiye kadar cahil kalmış olan genç ve ihtiyar bilcümle ümmet-i Muhammed, cahilliğin dareynde (dünya ve ahiret) vahametini düşünüp ve bu bapta birbirinden utanmayarak, hemen Hak'tan utanıp kendileri bulundukları kâr-1 kisb (kazanç) ve sanat ve hizmetleri arasında bilmedikleri mesâil-i diniye ve akaid-i İslâmiye'lerini dahi öğrenip bilmekle, hasbel imkân sa'y-u gayret (çalışma) ve ol vecihle kendilerini dareyn selametliğine irgürmekliğine (ermek) sarf-1 vus'-i makderet (çok emek vermek) eylemeleri fâriza-i uhde-i diyânetleri (dini sorumlulukları) olduğundan başka fî mâ ba'd (bundan sonra), herkes evladlarını mürahik (buluğ) derecesine varmadıkça, ve ilmihal ve şerait-i İslâmiye'sini layıkıyle taallum etmedikçe (öğrenmedikçe) mektepten alıp ustaya vermemek ve mürahik olup ustaya vermek derecesine geldikte babas1, babas1 yok ise sair velisi olan kimesne (kimse), mürahik derecesinde olduğunu, eğer İstanbul sekenesinden ise İstanbul kadısı olan efendi tarafına ve Eyüp ve Üsküdar ve Galata sükkanından (sakinler) iseler, kadıları efendiler taraflarına, mektep hocasıyla beraber varıp ve çocuğu dahi götürüp gösterip taraf-i şer'den yedlerine (ellerine) memhur (mühürlü) izin tezkiresi almak ve izin tezkiresi (resmi belge) almadıkça esnaf taifesi sakirtliğe almamak; ve sakirtliğe alınmaklıkta esnaf kedhüdalarının (kahya) dahi re'y (görüş) ve marifetleri (bilgi) munzam olmak (gerekli) lazimeden olduğuna binaen, şayet esnaftan biri o makûle (tür) tezkiresiz çocuğu şakirtliğe alır ve babası ve validesi verir ise, okuduğu mektebin hocası veyahut mahallesinin imamı, doğru kadı efendilere haber vermek ve kadı efendiler dahi bu keyfiyeti ihya-i dini mübin kaziyesine (hüküm) mebni olduğundan, taraflarından taharrî olunarak (araştırılarak) izin tezkiresi almaksızın sanata verilmiş sabî (çocuk) bulunur ise, alanı ve vereni ve ol esnafın kethüdasını ve haber vermediği için mektep hocasını li ecli't-tedib (cezalandırmak için) Babıli'ye inha (resmi bildirim) eylemek. Anasızbabasız yetim çocuklar olup da kimesnesizliği (kimsesiz) sebebiyle zaruri, bir usta yanında veyahut bir kimesnenin terbiyesinde bulunur ise, ustas1 ve gerek mürebbisi olan adam, sırf sanat öğrenmekliğe ve hizmete hasretmeyerek (yoğunlaşmayarak) günde iki defa mektebe gönderip mürahik oluncaya kadar okutturmak ve kezalik (bunun gibi) el-haletü hazihî (mevcut durumda), ustalarda bulunan çocuklar dahi bi tıpkıha (aynen) bu nizama dahil olarak anası, babası veya sair velisi olanlar, ustadan alıp mektebe vermek ve kimsesiz olanları dahi ustaları mektebe verip cahil kalmamasına dikkat etmek ve mektep hocaları dahi mekteplerde bulunan çocukları güzelce okutup Kur'an-1 Azimü'ş şanı talim, akabinde (sonrasında) her bir çocuğun haysiyet ve istidadına göre tecvid ve ilmihal misillu risaleler okutarak serait-i İslâmiye ve akaid-i diniyelerini öğrenmekliğe sa'y u ikdam (sebatla çalışma) eylemek üzere, alel umûm (genellikle) tembih ve ikaz olunmasına irâde-i seniye (padişah fermanı) suduriyle (çıkarılmak) keyfiyet bilâd-ı selâse (üç belde) kadıları efendilere başka başka (ayrı ayrı) bâ fermân-1 âlî (yüce fermanla) tenbih kılınmış olmağla, siz dahi Asitanede (İstanbul) kâin bil cümle mahallat imamlarını ve mektep hocalarını ve esnaf kethüdalarını tarafınıza celb ederek (çağırarak), tembihat-1 mezkûreyi (adı geçen uyarıyı) gûş-i hûşlarına (can kulağı) telkin ve tefhim ve işbu ferman-1 âlînin birer mamzâ (imzalı) suretlerini dahi yedlerine (ellerine) ita-berle (vererek), imamlar mahalleleri ahalilerine ve kethüdalar dahi esnaflarına okuyup anlatmak ve mektep hocaları bilip mucibiyle (gereğince) amel etmek üzere cümlesine gereği gibi tembih ve te'kide 
mübaderet (hemen başlamak) ve bi-tevfikihi (Allah'ın yardımıyla) işbu nizam ve tembihatın ale'ddevam (devamlı) icra ve istikrar-1 vesâilini (vesilelerini) istihsâle (sağlamaya) tarafınızdan dahi bizzat ihtimam ve dikkat eyliyesiz deyü buyruldu (Ahmet Cevdet, 1309: 238-240).

Ferman'ın Osmanlıca Metni

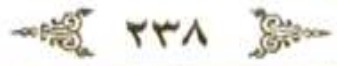

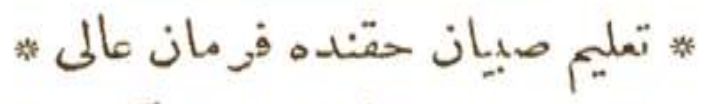

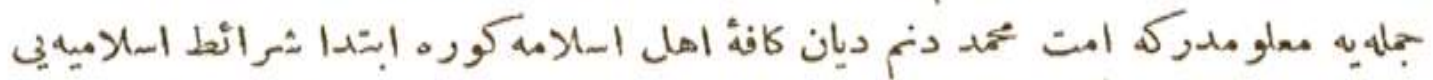

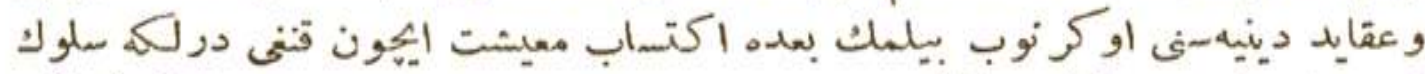

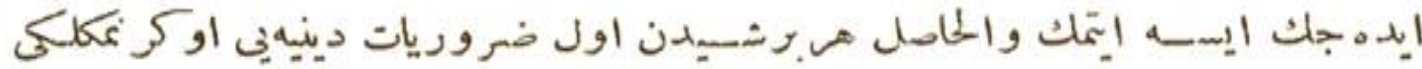

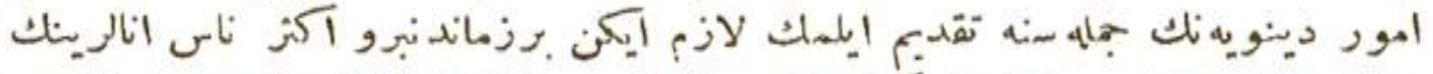

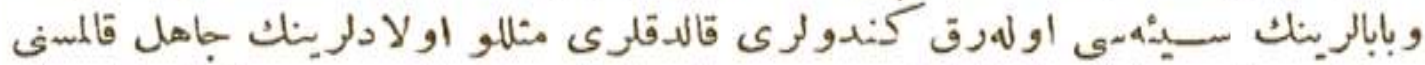

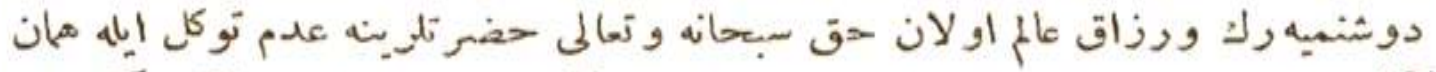

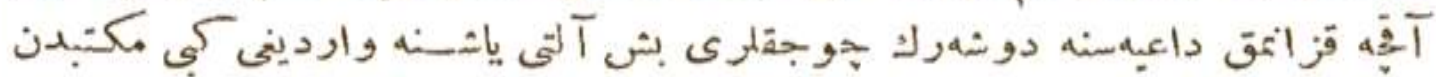

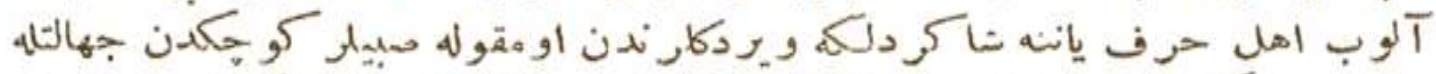

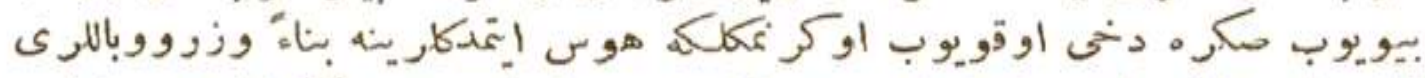

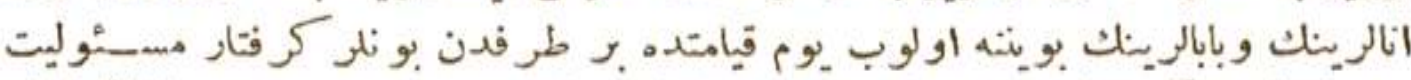

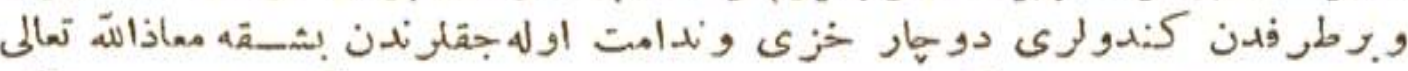

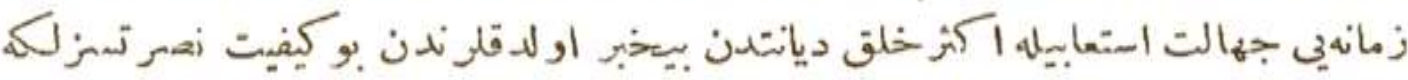

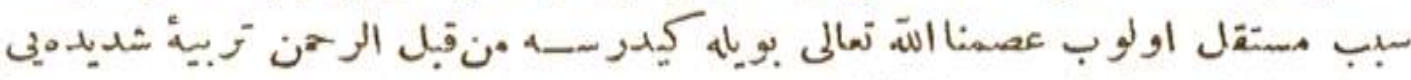

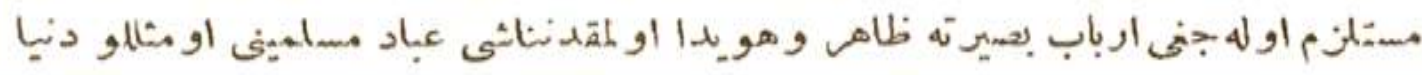

$$
(ت, T)
$$




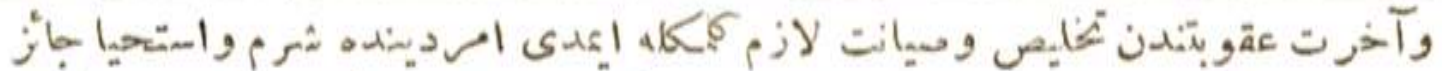

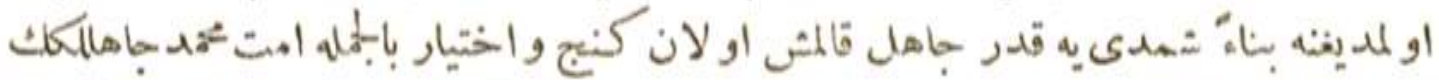

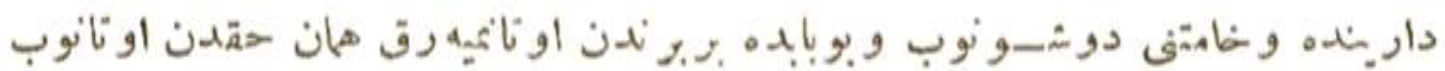

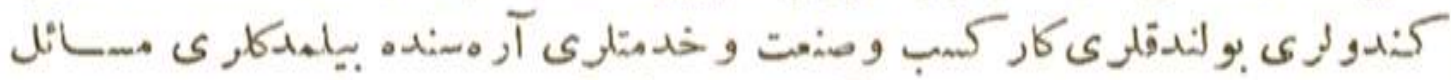

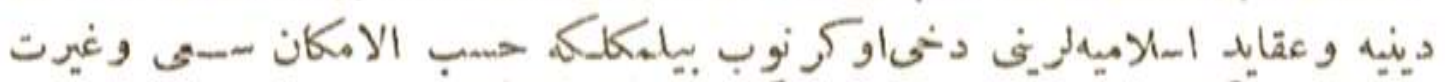

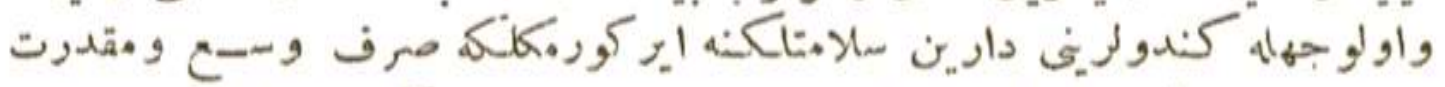

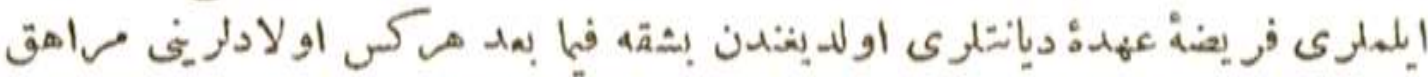

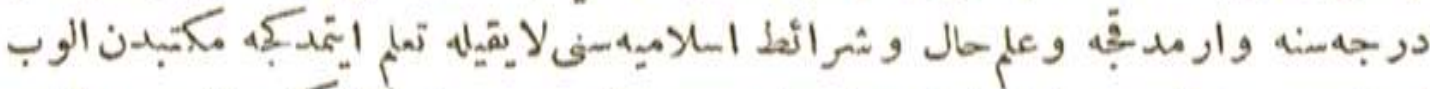

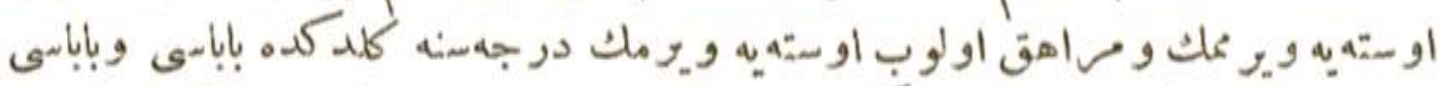

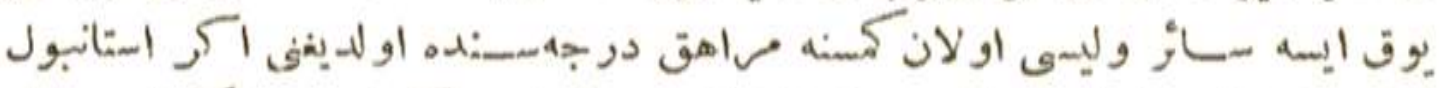

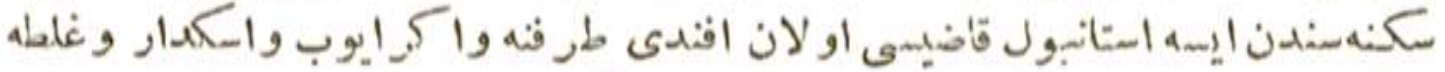

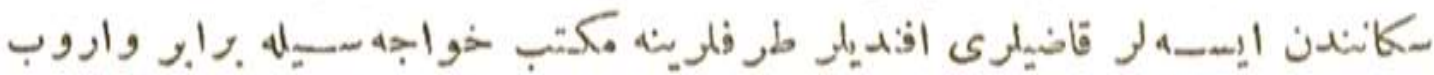

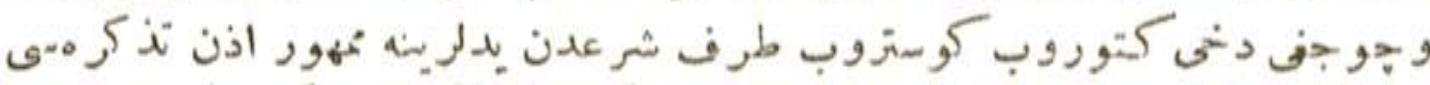

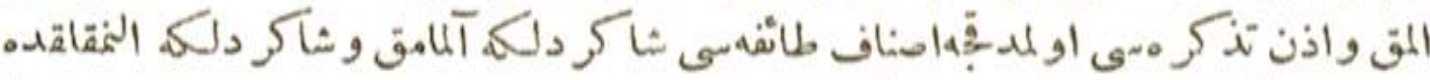

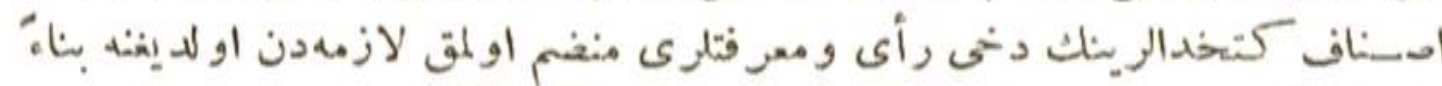

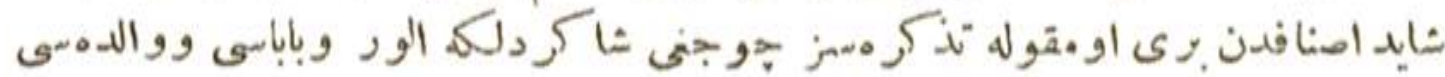

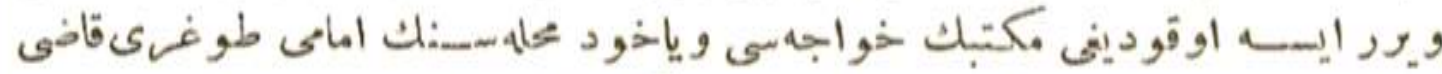

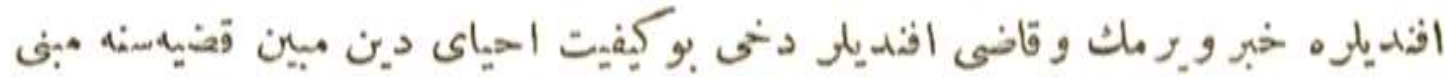

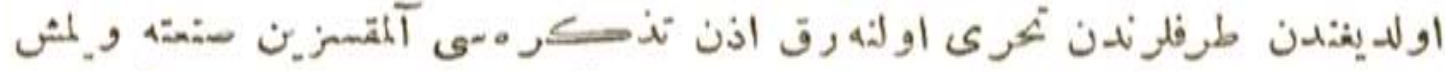

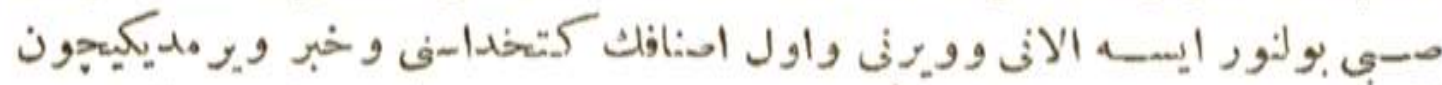

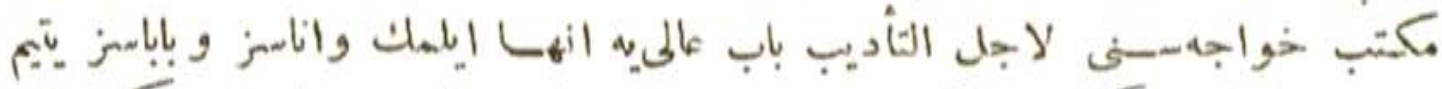

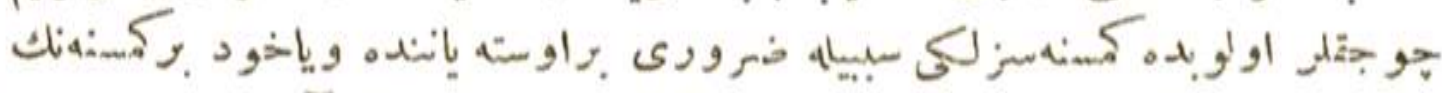

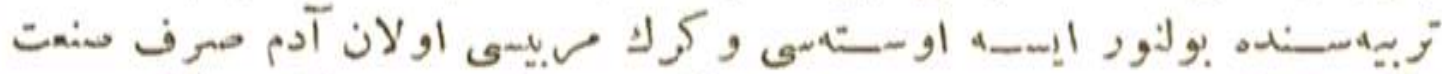

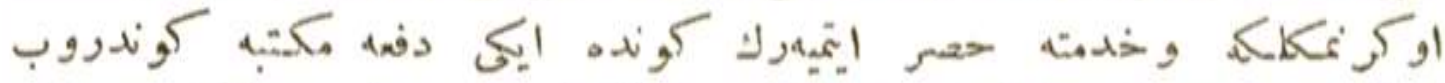

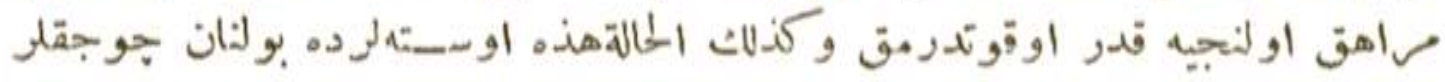

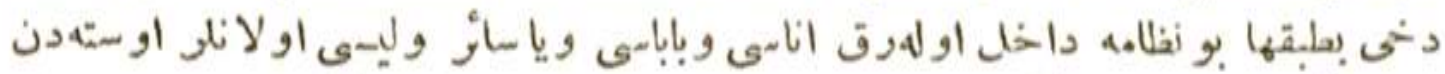

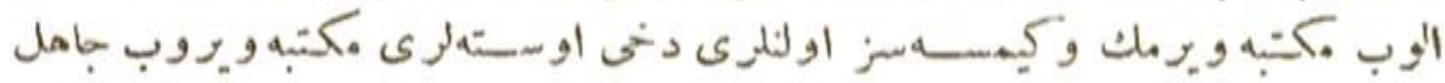

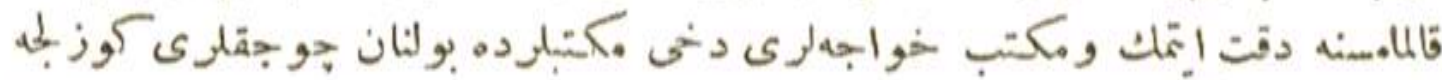

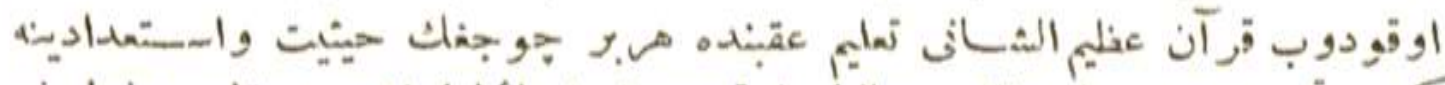

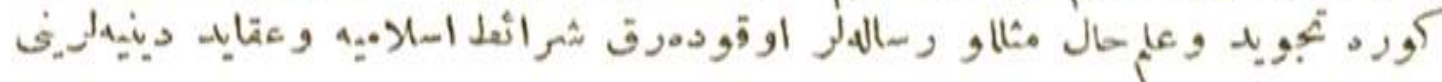




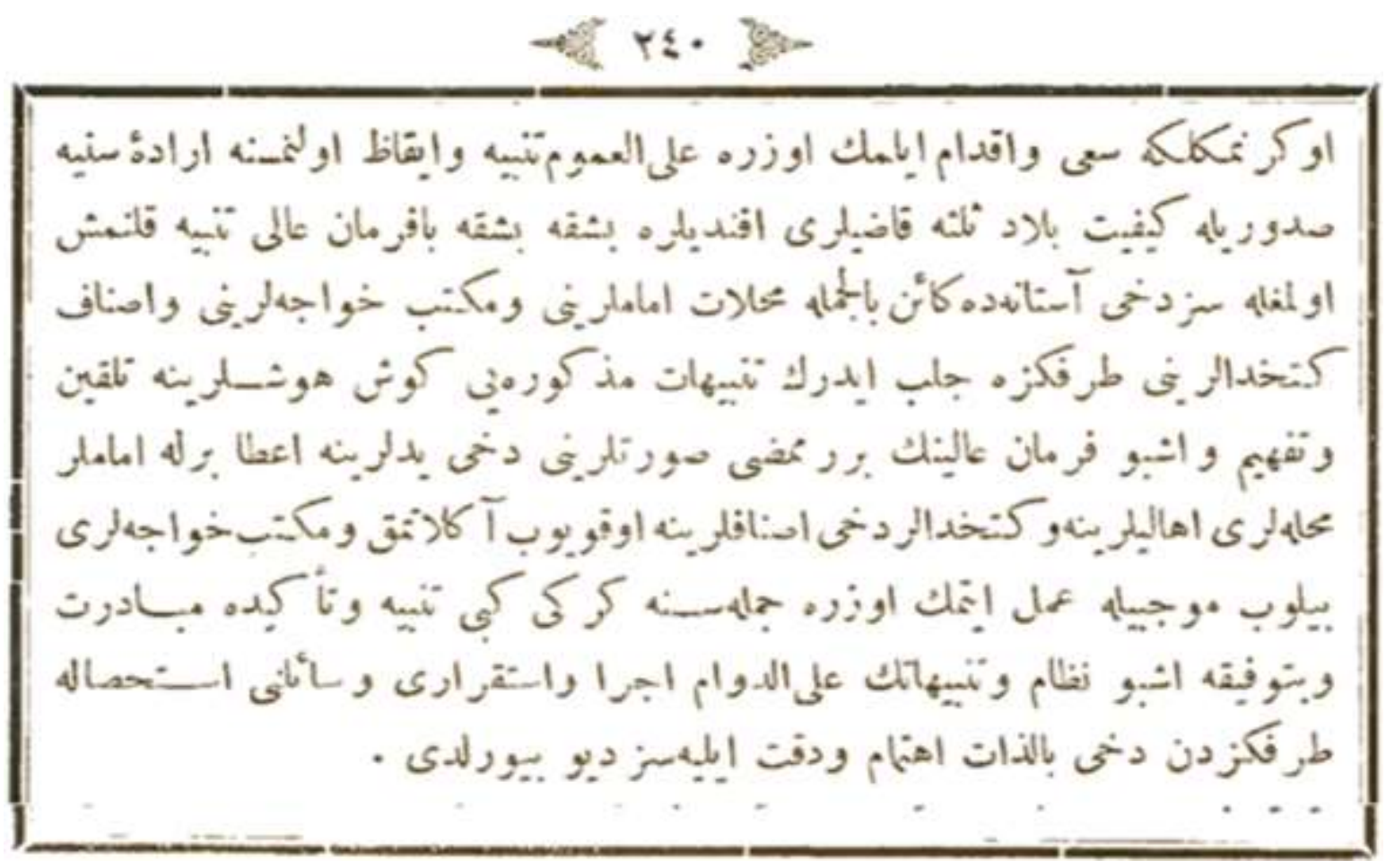

\subsection{Fermanın Genel Özelliği}

Padişah II. Mahmut tarafından 1824 yılında "Talim-i Sıbyan" adıyla yayınlanan fermanda temel eğitimde din eğitiminin önemi vurgulanmış, mevcut şartlarda ailelerin eğitime karşı tutumuna ilişskin bir durumun tespiti yapılmıştır. Fiili durumun sebep olabileceği sıkıntılara işaret edilerek fermanın hükümlerinin gerekçeleri sıralanmıştır. Ardından çocukların eğitimine ilişkin hükümlere yer verilerek, bunların icrası ve bu süreçteki yasaklar açıklanmıştır. Zorunlu hale getirilen eğitimin kontrolü için görevliler belirlenip, hükümlere riayet göstermeyenler için bir ihbar sistemi oluşturulmuştur. Anne-baba veya esnafın kuralları ihlali yahut görevlilerin ihbar sistemini işletmede gösterecekleri ihmalin cezalandırılması için kadılara, konuyu ayrıntılı araştırma görevi yüklenmiştir. Fermanın sonunda istisnai durumlara da açıklık getirilmiştir.

Ferman, bir anlamda klasik Osmanlı temel eğitim kurumu olan Sibyan mekteplerinin o dönemde içinde bulunduğu şartları yansıtmaktadır. II. Mahmud bu fermanla çocukların temel eğitiminin önemini vurgulamış, onları ebeveynin ve esnafın insafına terk etmeyerek, çıraklık yerine buluğ çağına kadar sıbyan mektebine gönderilmesini zorunlu hale getirmiştir. Böylece ferman, bir yandan eğitim hakkını kullanmada çocuğa yardımcı olurken diğer yandan da çocuk iş gücünün istismarını önleyerek çocuğun fiziksel ve ruhsal gelişimi için daha sağlıklı bir zemin hazırlamıştır. Ferman bu özelliğiyle Türk eğitim tarihinde olduğu kadar Türk çocukluk tarihinde de önemli bir belge hüviyetindedir. Hatta bu belgenin dünya çocukluk tarihinin ilk ve en önemli belgelerinden birisi olduğu söylenebilir.

Ferman ve içeriğinden pek çok araştırmada söz edilmesine rağmen orijinal nüshasıyla ilgili hiçbir bilgi verilmemiştir. Söz konusu fermanın orijinal nüshası için Başbakanlık Osmanlı Arşivinde tarafımızca yapılan araştırmadan da bir sonuç alınamamıştır. Bununla birlikte, Ahmet Cevdet'in 1309 tarihli "Tarihi Cevdet" adlı eserinin 12. Cildinin 238-240 sayfalarında "Talim-i Sibyan Hakkında Ferman-1 Âlı̂” başlığı altında fermanın tam metnine ulaşılmıştır. 


\subsection{Fermanda Vurgulanan Başlıca Konular}

Fermanda vurgu yapılan başlıca konular şöyle sıralanabilir:

- Temel dini bilgilerin öğretilmesinin zarureti,

- Ana-babaların duyarsızlığı yüzünden çocukların cahil kalması,

- Para hırsı ve çocuk iş gücünün istismarıyla sonuçlanan çocukların okul yerine işe gönderilmesi,

- Çocukları küçükken eğitmenin gerekliliği, büyüyünce bu işin zor olduğu,

- Cehaletin toplumdaki yaygınlığı ve bunun nusretsizliğe ve felakete sebep olabileceği,

- İş ve sanatı öğrenirken "zarûrâtı diniye" denilen şeylerin de öğrenilmesinin ihmal edilmemesi,

- Eğitimin dünya ve ahiret saadetini sağlayıcı olduğu,

- Çocukların buluğ çağına kadar çıraklığa verilemeyeceği,

- Buluğa ermiş çocukların durumunu gösterir resmî belge olmadan çıraklığa kabul edilmeyeceği,

- Çocuğun çıraklığa alınmasında esnaf kethüdalarının izninin olacağı,

- Emir ve yasaklara uymayanların resmi makamlara ihbar edilmesinin zorunluluğu,

- İhbar durumunda kadıların neler yapması gerektiği,

- Yetim ve kimsesiz çocuklara yönelik istisnaların neler olduğu,

- Mevcut durumda çırak olarak çalışanların da bu nizamname gereği mektebe verilmesi.

\subsection{Fermanın İçeriği}

Ferman, temel eğitimin yasal bakımdan zorunluluğunun bulunmadığı bir vasatta çıkarılmıştır. $O$ günün eğitim sorunu fermanda geniş bir açıdan ele alınarak, çözüme yönelik hükümler getirilmiştir. Fermanın içeriği; din eğitiminin önemi, mevcut durumun tespiti, fermanın gerekçesi, çocuklarla ilgili hükümler, yasaklar, ihbar sistemi, hocaların görevi, tecziye, halk eğitimi ve istisnalar şeklinde muhtelif başlıklar altında değerlendirilebilir.

Din eğitiminin önemi: Ferman, "Müslüman bir kimse için zarûrâtı diniye denilen temel dini bilgileri öğrenmenin, tüm dünya işlerinden daha öncelikli olduğu" hükmüyle başlar. Bu amaçla fermanın başlangıcında, öncelikle İslam'ın şartlarını, dini akidelerini öğrenmek daha sonra geçimini sağlayacağı uygun bir mesleğe yönelmek gerektiğine ilişkin uyarı niteliğinde bir tespit yapilmaktadır.

Mevcut durumun tespiti: Fermanın başlarında mevcut duruma ilişkin tespitlere yer verilmiştir. Ana-babaların ve esnafın çocukların eğitimi ile kendi kazançları arasında nasıl bir tercih yapma eğiliminde oldukları açıklığa kavuşturulmuştur. Mevcut durum; "Oysa bir müddettir, çoğu insanlar, anne babalarının hatası sebebiyle kendileri cahil kaldıkları gibi çocuklarının cahil kalmasını da önemsemiyorlar. Allah'a da tevekkül etmeyerek, hemen para kazanmaya başlamaları için çocuklarını 5-6 yaşlarında okuldan alıp bir sanatkarın yanında çıraklığa veriyorlar" şeklinde bir tespitle açıklığa kavuşturulmuştur.

Fermanın gerekçesi: Ferman, çocukların temel dini bilgileri öğrenemeden, çocuk yaşta iş hayatına atılmalarının sakıncalarına işaret etmektedir. Buna bağlı olarak fermanda bir taraftan çocukların eğitim hakkını kullanamayışına vurgu yapılırken diğer yandan çocuk işgücünün istismarına dikkat çekilmiştir. Okuyup öğrenmeden mahrum bırakılan o masum çocukların gelecekte eğitime devam edip etmeyecekleri de belli değildir. Yetişkinlikte de öğrenme heveslerini kaybettikleri, öğrenme ihtiyacı hissetmedikleri veyahut eksiklerini telafide utangaçlık gösterdikleri için öğrenmeden uzak durmaktadırlar. Böylece cehaletin yaygınlaşmasına zemin oluşmaktadır. Buna sebep olan ailelerin büyük sorumluluğu olduğu gibi kişilerin kendileri de hem dünyevi hem de uhrevi olarak bunun pişmanlığını yaşayacaklardır. Aynı şekilde cehaletin yaygınlaşması nusretsizliğe (ilahi 
yardımım kesilmesi) sebep olabileceği ve nihayetinde musibetlerin yaşanabileceği endişesi fermanda açık olarak görülmektedir. Böylece fermanın gerekçesi, eğitimsizliğin bireysel olarak çocuğa, anne babasına ve topluma verdiği zararlara dikkat çekilerek oluşturulmuştur.

Çocuklarla ilgili hükümler: Fermanla, buluğ çağına kadar çocukların temel eğitimlerini tamamlamaları zorunlu hale getirilmiştir. Bu süreçte çocukların okuldan alınıp çıraklığa verilmesi önlenmiştir. Temel dini bilgileri öğrenip buluğ çağını da idrak etmiş olan çocukların bu durumunun öğretmen, veli ve çocuğun birlikte kadıya giderek alacakları resmi belgeyle belgelenmesi istenmektedir. Bunun için İstanbul bölgesinde oturanların İstanbul kadısından, Eyüp, Galata ve Üsküdar semtlerinde oturanların da kendi bölgelerindeki kadıya başvurmaları gerektiği belirtilmiştir. Ferman yayımlandığı sırada bir usta yanında çıraklıkta bulunan çocuklar da aynen bu nizama tabi olarak ana-babası veya velisi tarafından ustadan alınıp mektebe vermeleri gerektiği belirtilmiştir.

Yasaklar: Fermanla buluğ çağına gelmemiş çocukların çalıştırılması yasaklanmıştır. Temel eğitimini almış ve buluğ çağına ulaşmış olsa da bu durumu resmi makamlardan alınmış imzalı bir belgeyle belgeleyemeyen çocukların esnaf tarafından çıraklığa alınması da yasaklanmıştır. Çocuğun çıraklığa kabulünde esnaf kethüdasının izni zorunlu tutulmuş, onun bilgisi olmadan herhangi bir çocuğun çıraklığa kabul edilmesi de yasaklanmıştır.

İhbar sistemi: Fermanda yasakların ihlali durumunda devreye girecek bir ihbar sistemi de oluşturulmuştur. Bu sistem okul çağındaki çocuklarını çıraklığa veren ana-babalarla, o çocukları çıraklığa kabul eden esnafın resmi makamlara bildirilmesini emretmektedir. İhbarla görevli olan kişiler mahallenin imamı, -ki genellikle aynı zamanda mektebin görevlisi de olabilir- o çocuğu okutmakla görevli mektebin hocasıdır. Bunlar durumu ilgili kadıya bildirmekle görevlidirler.

Cezalandırma: Fermanda yasakları ihlal edebilecekler dört zümre halinde ifade edilmiştir. Bunlar; okul çağı çocuklarını çıraklığa verenler, onları çıraklığa kabul edenler, esnaf kethüdası ve ihbar görevini ihmal eden mektep hocasıdır. Kadı, bunları resmi bir yazı ile Bâb-i Âliye (hükümete) bildirilmekle görevlidir. Yasakları ihlal edenlerin cezalandırılması için bir ihbar sistemi kurulmuş olsa da ne tür ceza öngörüldüğü hakkında fermanda bir açılamaya yer verilmemiştir.

Hocaların görevi: Fermanda hocaların niteliğinden söz edilmemekle birlikte onların görevleri hakkında kısa açıklamaya da yer verilmiştir. Hocalardan, mektebe gelen çocukları güzelce okutup Kur'an'1 öğretmeleri, her bir çocuğun seviyesi ve yeteneğine göre tecvid ve ilmihal gibi küçük kitaplar okutmaları, İslam'ın şartlarını, dinin inanç esaslarını öğretmeleri istenmektedir. Öğretmenlik görevini sabır, gayret ve sebatla uygun şekilde yerine getirmeleri istenmiştir. Bu ifadelerden öğretmenlerin sahip olması gereken kişisel ve mesleki nitelikler hakkında bir fikir edinmek mümkündür.

İtisnalar: Fermanın son kısmında uygulanacak istisnalara yer verilmiştir. Buna göre ferman hükmünden istisna olarak sorumlu tutulanlar sadece anasız-babasız, yetim çocuklardır. Onlar kimsesizlik sebebiyle zaruri bir usta yanında çalışmak zorunda kalabilirler. Böyle bir durumda çocuğun gerek ustası ve gerek velisi, çıraklığı sürdürmekle birlikte, buluğa erinceye kadar günde iki defa mektebe gönderip orada ders görmelerini sağlamalıdır.

Halk eğitimi: Fermanda geçmişe dönük ihmallerin telafisi için halk eğitimine de vurgu yapılmıştır. Özellikle din konusunda utanıp arlanmanın caiz olmadığı belirtilerek, şimdiye kadar cahil kalmış olan genç-ihtiyar herkesin eksiklerini tamamlamada gayret göstermeleri istenmiştir. Cehaletin hem dünyada hem de ukbada felaketlere sebep olacağına vurgu yapılarak öğrenmekten değil cehaletten, insanlardan değil yaratandan utanmak gerektiği belirtilmiş, mesleklerini icra etme sürecinde bilgilerindeki eksiklikleri de tamamlamaya önem vermeleri istenmiştir. 


\section{Fermanın Çağdaş Çocuk Hakları Açısından Değerlendirilmesi}

Dünyada çocuk haklarına ilişkin en gelişmiş ve bağlayıcı belge olan Birleşmiş Milletler Çocuk Hakları Sözleşmesinde çocuk hakları; "yaşama"," gelişme", "katılım" ve "korunma" gibi dört temel alanda güvenceye kavuşturulmuştur. İnceleme konusu edinilen "Talim-i Sıbyan Fermanı"nın da adı geçen sözleşmede güvence altına alınan dört temel alandan "gelişme" ve "korunma" haklarını güvence altına almaya yönelik olduğu görülmektedir.

Fermanın yayımlandığı döneme kadar Osmanlı'da, çocukların zorunlu olarak okula gönderilmesini gerektirecek bir uygulama olmadığı gibi çocukların bir an önce iş ve meslek hayatına atılmalarını önleyecek bir düzenleme de mevcut değildi. Bu konu tamamen ana-babaların tercihine ve esnaf ve sanatkarın kabulüne dayalı olarak yürütülmekteydi. Ülkedeki en yaygın öğretim kurumu olan sıbyan mekteplerinin kuruluşundan personel ataması, giderleri ve programlarına kadar hiçbir aşamasında devlet herhangi bir inisiyatif üstlenmemişti. Görev tamamen gönüllü kuruluşlar yahut ihtiyacı hisseden halka bırakılmıştı. Padişah II. Mahmut'un 1824 tarihinde yayımladığ "Talim-i Sıbyan Fermanı" ile çocukların temel eğitimi konusu, ana-babaların ve esnafin insafina terk edilmekten çıkarılmış, devlet ilk defa çocukların korunması ve eğitimiyle ilgilenmeye başlamıştır.

Fermanda öne çıkan iki hususun; "temel eğitimin zorunluluğu" ve "çocuk işgücünün istismarının önlenmesi" olduğu görülmektedir. Bunlardan ilki, çocuğun "gelişim hakkı", ikincisi, "korunma hakkı" ile ilgilidir. Fermanın özünde, ailelerin çocuk işgücünün sağlayacağı maddi gelire, çocukları çalıştıran esnafın da ucuz işgücüne tamah etmelerine engel olma amacı belirgindir. Anababanın ve esnafın daha çok kazanma hırsı çocukların hem zihinsel hem de bedensel gelişmelerini olumsuz etkilemekteydi. Çocukların bu şekilde istismarını önlemek amacıyla fermanda cezai müeyyideler öngörülmüştür. Bu yönüyle ferman, çocuğun yetişmesi, bedensel, zihinsel, duygusal, sosyal ve ahlaki gelişimine dönük eğitsel önlemlerin alınması bakımından günümüz çocuk hakları anlayışıyla uyum göstermektedir.

\section{Sonuç}

Çocuklara ilişkin hakların belirlenmesi ve çocuğun korunması, geçmişten günümüze en önemli toplumsal problemlerden biri olarak halen varlığını devam ettirmektedir. Çocukların aciz ve korunmaya muhtaç varlıklar olması, yetişkinlerin onların gelişip yetişmelerinde aktif görev üstlenmelerini zorunlu kılmaktadır. Bu yönüyle çocuk yetiştirilmesi tarih boyunca hemen her toplumun hayatında önemli bir yer tutmuştur. Devletler bu konuyu bireylerin insafina terk etmemiş, her ülke kendi içinde birtakım önlemler ve çareler geliştirmiştir. Küresel dünya şartları bu çalışmaların uluslararası bir hüviyete bürünmesini zaruri hale getirmiştir. Bu zaruretin doğal bir sonucu olarak da konuyla ilgili birçok uluslararası metin oluşturulmuştur.

Çocuk haklarının korunmasına yönelik uluslararası nitelikte en son belge, 1989 tarihinde kabul edilen "Birleşmiş Milletler Çocuk Hakları Sözleşmesi" olup bu alanda en kapsamlı ve bağlayıcı belge niteliği taşımaktadır. Toplam elli dört maddeden oluşan sözleşmenin hükümlerinde çocuk hakları; yaşama, gelişme, katılım ve koruma gibi dört temel alanda toplanmaktadır. Çocuk Hakları Sözleşmesinden yaklaşık 155 yıl önce Padişah II. Mahmut'un Talim-i Sıbyan Fermanı; çocuğun gelişme ve korunma haklarını gündeme taşımış ve bunları korumaya yönelik müeyyide getirmiştir. Bu yönüyle sözleşme Türk ve dünya çocukluk tarihi açısından son derece önemli bir belgedir.

Bununla birlikte söz konusu belge hakkında günümüze kadar pek çok değerlendirme yapılmıştır. Bu değerlendirmelerin tamamı fermanı, Türk eğitim tarihinde eğitimi zorunlu hale getiren ilk yasal belge olması yönüyle değerlendirme konusu edinmiştir. Bu yönüyle çocuğun eğitim hakkına, dolaylı olarak işaret edilmiş olsa da çocuğun ihmal ve istismarını önlemeye yönelik boyutu göz ardı edilerek değerlendirme dışı tutulmuştur. 
$\mathrm{Bu}$ çalışmayla, çok bilinen ve hakkında birçok değerlendirmeler yapılmış olan "Talim-i Sıbyan Fermanı" yeni bir değerlendirmeye tabi tutularak çağdaş çocuk hakları açısından değerlendirilmiştir. Böylece söz konusu belgenin çocuk hakları açısından öneminin fark edilmesi için fermana yeni bir bakış getirilmiştir.

\section{Kaynakça}

Ahmet Cevdet (1309), Tarihi Cevdet, Matbaa-i Osmaniye Cilt 12 ss.238-240.

Akşam Gazetesi (2018), Dünya Çocuk Hakları Günü, 21 Kasım 2018.

Akyüz, E. (2012), Çocuk Hukuku, Pegem Akademi Yayınları.

Akyüz, E.(1999), Cumhuriyet Döneminde Çocuk Hukukundaki Gelişmeler, Cumhuriyet ve Çocuk, II. Ulusal Çocuk Kültürü Kongresi Bildirileri 4-6 Kasım 1998, Yayına Hazırlayan Prof.Dr. Bekir Onur, Ankara Üniversitesi Çocuk Kültürü Araştırma ve Uygulama Merkezi Yayınları.

Akyüz, Y. (2019), Türk Eğitim Tarihi, Pegem Akademi Yayınları.

Akyüz, Y. (1994), İlköğretimin Yenileşme Tarihinde Bir Adım: Nisan 1847 Talimatı, Ankara Üniversitesi Osmanlı Tarihi Araştırma ve Uygulama Merkezi Dergisi, S.5, ss. 1-47.

Bandırmalızâde, Seyid Ahmet Münib El Üsküdari (1318), Hukuk-u Veled, Cemal Efendi Matbaası.

Baykara, T. (2001), Türk Kültür Tarihine Bakışlar, Atatürk Kültür Merkezi Yayınları.

Bumin, K.(1983), Batıda Devlet ve Çocuk, Alan Yayıncılık.

Canan, İ.(1980), İslam'da Çocuk Hakları, Yeni Asya Yayınları.

ÇKK (2005), Çocuk Koruma Kanunu, 5395; https://www.tbmm.gov.tr 'den alınmıştır.

Doğan, İ. (2000), Akıllı Küçük, Sistem Yayıncılık.

Elkind, D. (1994), Değişen Dünyada Çocuk Yetiştirme ve Eğitim, Çev. Emine Gül Kapçı Toplumsal Tarihte Çocuk, Sempozyum, 23-24 Nisan 1993, Yayına Hazırlayan: Bekir Onur, Tarih Vakfı Yurt Yayınları.

Ergün, M. (2018), Modern Eğitim Sistemlerinin Doğuşu ve Gelişimi, C.1, Pegem Yayınları.

Gander, M. J.\& Gardiner, Harry W. (2004), Çocuk ve Ergen Gelişimi, Yayıma Hazırlayan, Prof. Dr. Bekir Onur, imge Kitabevi Yayınları.

Gazali, (1996) İslam Ahlakı, Tercüme: Akif Nuri, Sinan Yayınevi.

Gazali (1979), Kimya-i Saadet, Terc: A, Faruk Meyan, Bedir Yayınevi.

Gökalp, Z. (1991), Türk Uygarlığı Tarihi, Hazırlayan: Yusuf Çotuksöken, İnkılâp Kitabevi.

Gören, Z. (2017), Janusz Korczak’ın İzinde Günümüzde Çocukların Temel Hakları, İstanbul Ticaret Üniversitesi Sosyal Bilimler Dergisi, Say1:32, s. 43-67.

Gurbetoğlu, A. (2014), Eğitim ve Tarih, Ĕgitim Bilimine Giriş, ed: Mehmet Taşpınar, Edge Akademi Yayınları.

Gurbetoğlu, A. (2008), II. Meşrutiyet'te Çocuk Hakları Alanında Bir Dergi: "Musavver Hukuk-i Etfal”, Ankara Üniversitesi Eğitim Bilimleri Fakültesi Dergisi, C.41, Özel Sayı, 201-219.

Kafesoğlu, İ.(1998), Türk Millî Kültürü̈, Ötüken Neşriyat.

Kepenekçi, Y. K. (2000), İnsan Hakları Eğitimi, Anı Yayınları. 
Kant, İ. (2007), Eğitim Üzerine, Türkçesi: Ahmet Aydoğan, Say Yayınları.

Mutluay, N. (2007), Yunan ve Roma Uygarlı̆̆ında Çocuk, Ütopya Yayınları.

Onur, B. (1994), Sunuş, Toplumsal Tarihte Çocuk, Sempozyum, 23-24 Nisan 1993, Yayına Hazırlayan: Bekir Onur, Tarih Vakfi Yurt Yayınları.

Ögel, B. (2000), Türk Kültür Tarihine Giriş, C. 1, Kültür Bakanlığı Yayınları.

Polat, O. (2008), Türkiye'de Çocuk Haklarının Durumu, Toplum ve Demokrasi, C.2, S.2, OcakNisan, s. 149-157.

Postman, N. (1995), Çocukluğun Yok Oluşu, Çeviren: Kemal İnal, İmge Kitabevi.

Roux, J. P. (2008), Türklerin Tarihi Pasifikten Akdenize 2000 Yıl, Çevirenler: Aykut Kazancıgil, Lale Arslan-Özcan, Kabalcı Yayınları.

Tan, M. (1994), Çocukluk: Dün ve Bugün, Toplumsal Tarihte Çocuk, Sempozyum, 23-24 Nisan 1993, Yayına Hazırlayan: Bekir Onur, Tarih Vakfi Yurt Yayınları.

TCK (2004), Türk Ceza Kanunu, 5237; https://www.tbmm.gov.tr’ den alınmıştır.

TDV (1999), Türkiye Diyanet Vakfi İslâm Ansiklopedisi, Islahhane maddesi, C. 19, ss.190-191, Diyanet Vakfi Yayınları. 